\title{
ICP-MS Determination of 23 Elements of Potential Health Concern in Liquids of e-Cigarettes. Method Development, Validation, and Application to 37 Real Samples
}

\author{
Andrea Mara ${ }^{1}$ (D), Ilaria Langasco ${ }^{1}\left(\mathbb{D}\right.$, Sara Deidda ${ }^{1}$, Marco Caredda ${ }^{2}$, Paola Meloni $^{1}$, Mario Deroma $^{3}$, \\ Maria I. Pilo ${ }^{1} \mathbb{D}$, Nadia Spano $^{1} \mathbb{D}$ and Gavino Sanna ${ }^{1, * \mathbb{D}}$ \\ 1 Dipartimento di Chimica e Farmacia, Università degli Studi di Sassari, Via Vienna 2, 07100 Sassari, Italy; \\ a.mara@studenti.uniss.it (A.M.); ilangasco@uniss.it (I.L.); saradeidda96@tiscali.it (S.D.); \\ paola94meloni@gmail.com (P.M.); mpilo@uniss.it (M.I.P.); nspano@uniss.it (N.S.) \\ 2 AGRIS Sardegna, Loc. Bonassai, S.S. 291 Km 18.6, 07100 Sassari, Italy; mcaredda@agrisricerca.it \\ 3 Dipartimento di Agraria, Università degli Studi di Sassari, Viale Italia 39/a, 07100 Sassari, Italy; \\ mderoma@uniss.it \\ * Correspondence: sanna@uniss.it; Tel.: +39-079-229-500
}

\section{check for} updates

Citation: Mara, A.; Langasco, I.; Deidda, S.; Caredda, M.; Meloni, P.; Deroma, M.; Pilo, M.I.; Spano, N.; Sanna, G. ICP-MS Determination of 23 Elements of Potential Health Concern in Liquids of e-Cigarettes. Method Development, Validation, and Application to 37 Real Samples. Molecules 2021, 26, 6680. https:// doi.org/10.3390/molecules26216680

Academic Editor: Pawel Pohl

Received: 13 October 2021

Accepted: 29 October 2021

Published: 4 November 2021

Publisher's Note: MDPI stays neutral with regard to jurisdictional claims in published maps and institutional affiliations.

Copyright: (c) 2021 by the authors. Licensee MDPI, Basel, Switzerland. This article is an open access article distributed under the terms and conditions of the Creative Commons Attribution (CC BY) license (https:/ / creativecommons.org/licenses/by/ $4.0 /)$.

\begin{abstract}
The lack of interest in the determination of toxic elements in liquids for electronic cigarettes (e-liquids) has so far been reflected in the scarce number of accurate and validated analytical methods devoted to this aim. Since the strong matrix effects observed for e-liquids constitute an exciting analytical challenge, the main goal of this study was to develop and validate an ICP-MS method aimed to quantify 23 elements in 37 e-liquids of different flavors. Great attention has been paid to the critical phases of sample pre-treatment, as well as to the optimization of the ICP-MS conditions for each element and of the quantification. All samples exhibited a very low amount of the elements under investigation. Indeed, the sum of their average concentration was of ca. $0.6 \mathrm{mg} \mathrm{kg}^{-1}$. Toxic elements were always below a few tens of a $\mu \mathrm{g}$ per $\mathrm{kg}^{-1}$ and, very often, their amount was below the relevant quantification limits. Tobacco and tonic flavors showed the highest and the lowest concentration of elements, respectively. The most abundant elements came frequently from propylene glycol and vegetal glycerin, as confirmed by PCA. A proper choice of these substances could further decrease the elemental concentration in e-liquids, which are probably barely involved as potential sources of toxic elements inhaled by vapers.
\end{abstract}

Keywords: e-cigarettes; e-liquids; toxic elements; trace elements; ICP-MS

\section{Introduction}

Electronic cigarettes (e-cigarettes) were introduced on the market in the mid-2000s and are considered a healthier alternative to traditional smoking. There are different types of devices, components, and e-liquids [1,2] to meet all consumer needs. However, all of them share the same components as well as principle of functioning. It consists of a power source, such as a rechargeable lithium battery, and a cartridge (or a tank) containing the liquid (henceforward called e-liquid). An electrical resistance (i.e., the atomizer), activated by a puff or by a button, is the heating element, which promotes the nebulization of the e-liquid and the formation of the aerosol inhaled by the vaper. An electronic system may be able to report the information related to the nebulization process (volts, watts, ohms, puffs) from a smartphone, LEDs, or an integrated screen. The flavored e-liquid is mainly formed by low amounts of water and two EU food additives, namely propylene glycol (E1520, according to the EU classification, (PG)) [3] and vegetal glycerin (E422, (VG)) [4]. Both generally recognized as safe (GRAS) by the U.S. Food and Drug Administration. In addition, it may contain variable amounts of nicotine, never exceeding the concentration of $20 \mathrm{mg} \mathrm{cm}^{-3}$ in EU countries [5]. 
Although they are considered healthier than traditional cigarettes, owing to their lack of toxic products formed by combustion [6-9], the health risks related to the use of e-cigarettes have also been widely studied [10-13]. The apparatuses mainly involved are the respiratory [14,15], the cardiovascular [16,17], the nervous [18], and the reproductive systems [19]. Nicotine [20] is likely one of the most toxic components assimilated by means of tobacco smoke. It is quickly assimilated [21] and adversely affects respiratory, cardiovascular, renal, and reproductive systems [22]. However, the presence of nicotine in e-liquids is optional, and it may be dosed to accomplish any nicotine replacement therapy needs. In a close analogy to what happens with traditional tobacco smoke, attention has been paid to the formation of potentially harmful compounds from the thermal degradation of the main ingredients of e-liquids, such as the flavors, PG and VG [23-25]. Hence, chromatographic methods devoted to determining species such as nitrosamines, VOCs, carbonyls, polycyclic aromatic hydrocarbons, and aldehydes have been developed for this purpose [26-29]. Nevertheless, and only with some exceptions [30], the absence of any combustion process and the low temperatures measured in the nebulization process of eliquids greatly reduce the concentration and the number of harmful species in comparison to what is observed in the smoke of traditional cigarettes [7]. Moreover, the concentration of toxic metals and metalloids contained in the aerosol of e-cigarettes seems lower than that measured in traditional smoke [31-33]. Although, Badea et al. measured detectable amounts of rare earths in the serum of e-cigarette smokers [34]. Moreover, in this case, many analytical methods for the determination of elements in aerosols and-more rarely -in e-liquids were recently developed [35]. Only in a few cases, elemental determination is carried out on both liquids and aerosols [25,36-38]. In these contributions, the concentration of the elements measured was higher in aerosols rather than in e-liquids, with the only exception being the study performed by Beauval et al. [25], where the amount found in both matrices was comparable. The elemental amounts found in these studies are hardly comparable among them, due to the great differences in e-cigarettes, e-liquids, and sampling techniques and puffing protocols in the aerosol determination [39,40].

Moreover, the analytical technique used for elemental determination is a possible reason for the differences observed among the literature studies. Inductively coupled plasma (ICP) methods (e.g., ICP-mass spectrometry (ICP-MS) [7,25,33,36-46] or ICPoptical emission spectroscopy (ICP-OES) [47-50]) are the instrumental techniques mainly used for this purpose, although sometimes X-ray fluorescence methods have also been used [51]. As far as the toxic elements are concerned, those most frequently measured are As [7,25,36,37,39,41-45,49,51], Pb [7,25,33,36,37,41,43-45,47,51], Cd [7,25,33,36,37,41-45,51], and Cr [7,25,33,36,39,41,43-45,47,48,51], while sometimes also Sn [36,39,44,45,47-49], $\mathrm{Sb}[25,36,39,41,49], \mathrm{Hg}[25,41,44,45]$, and $\mathrm{Tl}[25,41]$ were quantified.

Although it may seem obvious that determining the amounts of elements that are potentially health-threatening contained in e-liquids might be important in defining the overall level of exposure of vapers, until now the limits posed (or suggested) by countries [52,53] or international organizations [54] on the concentration of toxic elements are quite rare. This also reflects the scarce number of literature contributions addressed to this aim. From a purely analytical viewpoint, it is surprising that the possibility of a severe bias in the ICP-MS determination of these analytes, caused by a matrix almost entirely formed by organic species such as e-liquids, was considered only by one research group [41]. In addition, only two research groups $[25,36,41]$ attempted to quantify a reasonable number among the toxic elements and oligoelements while, to the best of our knowledge, toxic elements such as $\mathrm{Ba}, \mathrm{Bi}$, and $\mathrm{U}$ were never quantified in e-liquids.

Therefore, the principal aim of this contribution was to develop and validate an ICP-MS method able to determine the total amount of the 23 elements of potential health concern, i.e., Al, As, B, Ba, Be, Bi, Cd, Co, Cr, Cu, Fe, Hg, Li, Mn, Mo, Ni, Pb, Se, Sb, Sn, Tl, U, and $\mathrm{Zn}$, in a reliable sampling of e-liquids produced in Sardinia, Italy. Particular attention has been taken to optimize critical phases such as sample pre-treatment and quantification method. Samples were analyzed simply after a proper dilution or after microwave-assisted 
mineralization, whereas external calibration (in the absence or in the presence of the matrix) and internal calibration were kept into consideration for quantification. Since the need for studies aimed to evaluate the role of the flavor components in the contamination by trace elements in e-liquids was evidenced in previous publications [25], the optimized methods were tested on 37 different flavors and on the constituents of all e-liquids (i.e., PG, VG, water, and nicotine).

\section{Results and Discussion}

\subsection{Method Assessment}

\subsubsection{Sample Pre-Treatment}

The technique of sample pre-treatment most frequently described in the literature for e-liquids $[25,36,37,41]$ is a simple dilution in an $\mathrm{HNO}_{3}$ aqueous solution, exploiting their complete solubility in such a solvent. However, the e-liquids may represent in principle a strongly interfering matrix in ICP-MS measurement, due to their very high amount (always over $95 \% w / w$ ) of organic matter. Consequently, low levels of dilution of e-liquids also potentially allow for quantifying the trace elements, but inevitably increase the noise and the interference of the carbon-based polyatomic ions (especially on the quantification of elements such as Cr and V [41]). On the other hand, high levels of dilution reduce bias due to matrix effects, but likely permit the quantification only of the most abundant elements. In order to allow a comparison with literature data, the first approach of sample pre-treatment chosen in this study was the dilution of e-liquids, according to Beauval et al. [25,41]. The same method was also used for pre-treating the pure organic constituents of the e-liquids (i.e., PG, VG, and nicotine). Hence, ca. $0.3 \mathrm{~g}$ of sample, exactly weighted on an analytical balance $\left( \pm 0.0001 \mathrm{~g}\right.$ uncertainty), was diluted to a final volume of $15 \mathrm{~cm}^{3}$ with an aqueous solution containing a $2 \%(v / v) \mathrm{HNO}_{3}$ solution and $0.1 \%(v / v)$ of Triton ${ }^{\mathrm{TM}} \mathrm{X}-100$. In addition, by weighting $1.5 \mathrm{~g}$ and $0.15 \mathrm{~g}$ of the sample (finale volume $15 \mathrm{~cm}^{3}$ ), 1:10 $(w / v)$ and 1:100 $(w / v)$ dilutions were also tested to optimize the method. All samples were filtered through a $0.22 \mu \mathrm{m}$ nylon filter prior to ICP-MS analysis. Unfortunately, a high number of ionic counts for blanks were observed for several analytes (i.e., for $\mathrm{Cr}, \mathrm{V}$, and $\mathrm{Zn}$ ) when the 1:10 and 1:50 dilutions were used, likely due to a very strong interference by polyatomic ions. Conversely, using a 1:100 dilution, this interference was reduced, but it was no more possible to quantify the trace analytes. In addition, the high amount of organic species conveyed to plasma causes serious instrumental issues, such as a thick deposit of soot in the RF coil, in the torch, and in the cones. For these reasons, after some preliminary tests, the pre-treatment for dilution was abandoned.

Another option for the decomposition of the organic matrix in the e-liquids is an acid/oxidant attack assisted by microwaves. An amount of $0.3 \mathrm{~g}$ of the sample, exactly weighted on an analytical balance, was treated with $0.5 \mathrm{~cm}^{3}$ of $\mathrm{HNO}_{3}$ and $6 \mathrm{~cm}^{3}$ of water inside a $15 \mathrm{~cm}^{3}$ internal volume polytetrafluoroethylene (PTFE) vessel. Due to the high amounts of polyols contained in this matrix, the operative conditions used were the best compromise among the maximization of the oxidizing power and the minimization of the risk of unpredictable and potentially violent reactions inside the vessels. Figure 1 shows the trends of the microwave power and of the internal temperature and pressure of the vessel.

The whole mineralization cycle lasts $70 \mathrm{~min}$. After this time, the vessels were opened at room temperature and the mineralized samples were diluted up to $15 \mathrm{~cm}^{3}$ and filtered through a $0.22 \mu \mathrm{m}$ nylon filter.

\subsubsection{ICP-MS Method}

Table 1 reports the instrumental parameters and the elemental settings used for the ICP-MS determination of 23 toxic elements and oligoelements in e-liquids. 


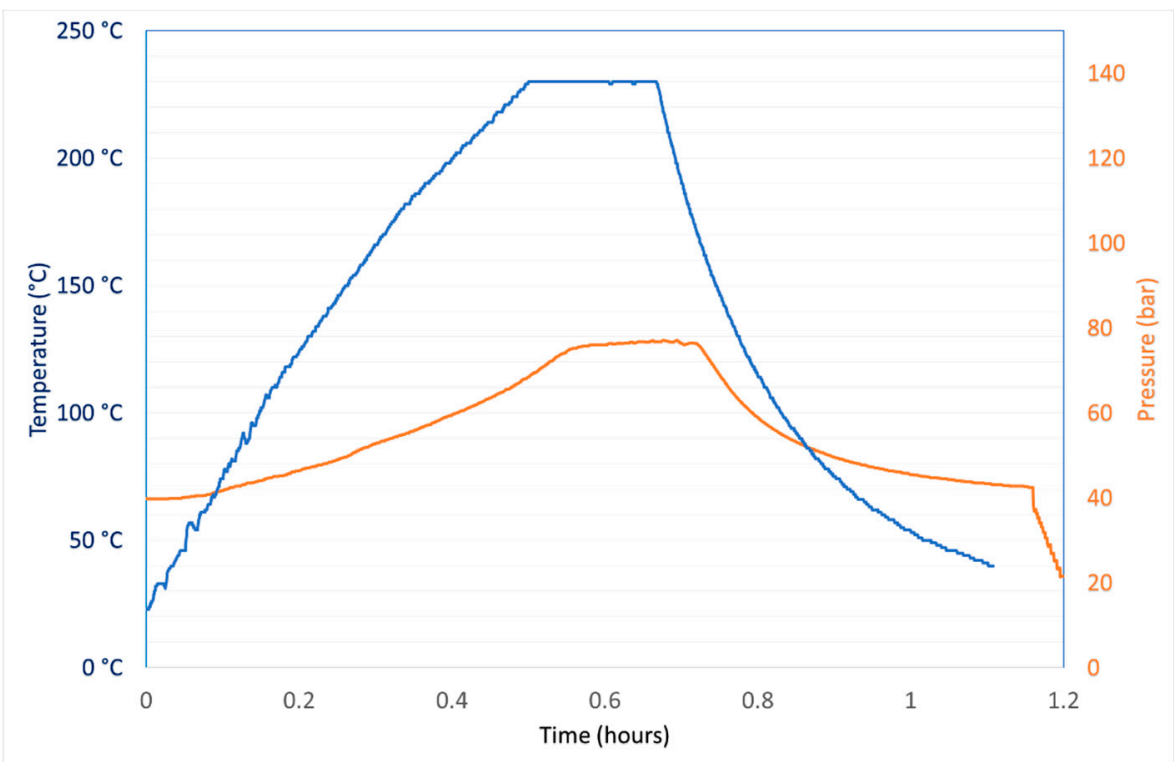

Figure 1. Trends of temperature and pressure inside vessels along a typical mineralization cycle of $0.3 \mathrm{~g}$ of an e-liquid dissolved in $0.5 \mathrm{~cm}^{3}$ of $\mathrm{HNO}_{3}$ and $6 \mathrm{~cm}^{3}$ of water.

Table 1. Instrumental parameters and elemental settings used for the ICP-MS determination of 23 toxic elements and oligoelements in e-liquids.

\begin{tabular}{|c|c|c|c|c|}
\hline RF power generator $(W)$ & 1300 & \multicolumn{2}{|c|}{$\mathrm{KED}^{\mathrm{a}}$ mode cell entrance voltage $(\mathrm{V})$} & -8.0 \\
\hline $\begin{array}{l}\text { Ar plasma flow } \\
\left(\mathrm{dm}^{3} \mathrm{~min}^{-1}\right)\end{array}$ & 18.0 & \multicolumn{2}{|c|}{ KED mode cell exit voltage (V) } & -25.0 \\
\hline $\begin{array}{l}\text { Ar auxiliary flow } \\
\left(\mathrm{dm}^{3} \mathrm{~min}^{-1}\right)\end{array}$ & 1.20 & \multicolumn{2}{|c|}{ Resolution (Da) } & 0.7 \\
\hline $\begin{array}{l}\text { Ar nebulizer flow } \\
\left(\mathrm{dm}^{3} \mathrm{~min}^{-1}\right)\end{array}$ & 0.91 & \multicolumn{2}{|c|}{ Scan mode } & Peak hopping \\
\hline Nebulizer & Meinhard $^{\circledR}$, glass & \multicolumn{2}{|c|}{ Detector mode } & Dual \\
\hline Spray chamber & Cyclonic, glass & \multicolumn{2}{|c|}{ Dwell time (ms) } & 50 \\
\hline $\begin{array}{l}\text { Skimmer and } \\
\text { sampling cones }\end{array}$ & Nickel & \multicolumn{2}{|c|}{ Number of points per peak } & 3 \\
\hline Sampling depth (mm) & 0 & \multicolumn{2}{|c|}{ Acquisition time (s) } & 6 \\
\hline Deflector voltage (V) & -8.00 & \multicolumn{2}{|c|}{ Acquisition dead time (ns) } & 35 \\
\hline Analog stage voltage (V) & -1750 & \multirow{2}{*}{\multicolumn{2}{|c|}{$\begin{array}{c}\text { KED gas } \\
\text { Masses of optimization }\end{array}$}} & Helium, 99.999\% \\
\hline Pulse stage voltage (V) & +1350 & & & ${ }^{7} \mathrm{Li},{ }^{89} \mathrm{Y}$ and ${ }^{205} \mathrm{Tl}$ \\
\hline $\begin{array}{l}\text { Quantification Ion } \\
\text { (\% abundance) }\end{array}$ & Interferents & Analyzing Mode & $\begin{array}{c}\text { He Flow } \\
\left(\mathrm{cm}^{3} \min ^{-1}\right)\end{array}$ & $\begin{array}{l}\text { Correction } \\
\text { Equation }\end{array}$ \\
\hline${ }^{27} \mathrm{Al}^{+}(100)$ & $\begin{array}{c}{ }^{11} \mathrm{~B}^{16} \mathrm{O}^{+} ;{ }^{13} \mathrm{C}^{14} \mathrm{~N}^{+} ; \\
{ }^{11} \mathrm{Be}^{16} \mathrm{O}^{+} ;{ }^{26} \mathrm{Mg}^{1} \mathrm{H}^{+} ;{ }^{12} \mathrm{C} \\
{ }^{15} \mathrm{~N}^{+} ;{ }^{54} \mathrm{Cr}^{2+} ;{ }^{54} \mathrm{Fe}^{2+} \\
{ }^{40} \mathrm{Ar}^{35} \mathrm{Cl}^{+} ;{ }^{59} \mathrm{Co}^{16} \mathrm{O}^{+}\end{array}$ & KED & 3.5 & none \\
\hline $75 \mathrm{As}^{+}(100)$ & $\begin{array}{c}{ }^{39} \mathrm{~K}^{36} \mathrm{Ar}^{+} ;{ }^{63} \mathrm{Cu}^{12} \mathrm{C}^{+} ; \\
{ }^{40} \mathrm{Ca}^{35} \mathrm{Cl}^{+} ;{ }^{58} \mathrm{Ni}^{16} \mathrm{O}^{1} \mathrm{H}^{+}\end{array}$ & KED & 3.0 & none \\
\hline${ }^{11} \mathrm{~B}^{+}(80.1)$ & none & Normal & & none \\
\hline $138 \mathrm{Ba}^{+}(71.7)$ & $\begin{array}{c}{ }^{40} \mathrm{Ar}_{2}{ }^{58} \mathrm{Ni}^{+} ;{ }^{138} \mathrm{La}^{+} ; \\
{ }^{122} \mathrm{Sn}^{16} \mathrm{O}^{+} ;{ }^{137} \mathrm{Ba}^{1} \mathrm{H}^{+} \\
{ }^{121} \mathrm{Sb}^{16} \mathrm{O}^{1} \mathrm{H}^{+}\end{array}$ & KED & 4.0 & $\begin{array}{l}-0.000901 \times{ }^{139} \mathrm{La} \\
-0.002838 \times{ }^{140} \mathrm{Ce}\end{array}$ \\
\hline${ }^{9} \mathrm{Be}^{+}(100)$ & none & Normal & & none \\
\hline $209 \mathrm{Bi}^{+}(100)$ & none & Normal & & none \\
\hline
\end{tabular}


Table 1. Cont

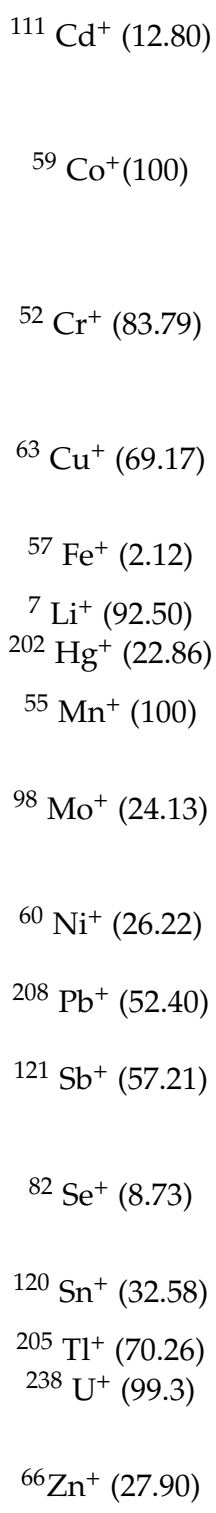

$$
\begin{gathered}
{ }^{40} \mathrm{Ar}^{16} \mathrm{O}^{1} \mathrm{H}^{+} ;{ }^{40} \mathrm{Ca}^{16} \mathrm{O}^{1} \mathrm{H}^{+} ; \\
{ }^{40} \mathrm{~K}^{16} \mathrm{O}^{1} \mathrm{H}^{+} \\
\text {none }
\end{gathered}
$$

4.0

none

KED

none

KED

KED

KED

Normal

Normal

KED

Normal

KED

Normal

KED

KED

KED

Normal

Normal

KED none

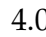

none

none

none

none

3.0

none

$$
-0.10961 \times{ }^{101} \mathrm{Ru}
$$

none

none

3.5

none

none

none

none

3.0

none

Whereas the elemental settings used for the determination of $\mathrm{Al}, \mathrm{As}, \mathrm{Cd}, \mathrm{Cr}, \mathrm{Cu}, \mathrm{Fe}, \mathrm{Hg}$, $\mathrm{Mn}, \mathrm{Mo}, \mathrm{Ni}, \mathrm{Pb}, \mathrm{Se}, \mathrm{Sb}, \mathrm{Tl}$, and $\mathrm{Zn}$ were from methods previously assessed by this research group [55-57], slightly modified to optimize them towards this matrix, those used to quantify $\mathrm{B}, \mathrm{Ba}, \mathrm{Be}, \mathrm{Bi}, \mathrm{Co}, \mathrm{Li}, \mathrm{Sn}$, and $\mathrm{U}$ were specifically devoted to e-liquids. In particular, the choice of quantification ion is extremely important for the overall reliability of the method. It should be the best compromise between the lowest LoD and the minimization of any possible interference. $\mathrm{Be}, \mathrm{Bi}$, and $\mathrm{Co}$ are monoisotopic, hence no alternative is possible. For elements showing a multiplicity of isotopes, the most abundant one provides generally the highest instrumental sensitivity, and this is a very appealing feature when very low concentrations must be measured. For this reason, ${ }^{11} \mathrm{~B},{ }^{138} \mathrm{Ba},{ }^{7} \mathrm{Li},{ }^{120} \mathrm{Sn}$, and ${ }^{238} \mathrm{U}$, respectively, were chosen for the quantification of these elements in this study. The interference from molecular ions (mainly from oxides, carbides, nitrides, hydrides, or Ar-based species formed in the plasma, but also from polyatomic ions that originated from elements contained in high amounts in the matrix) is one of the most meaningful 
causes of bias in ICP-MS measurements [58]. Its presence/absence for each analyte has been established based on the behavior of the ionic signal measured at the increasing of He flows. A change of the slope of the decreasing trend of the ionic signal measured on a real sample at the increasing of the He flow accounted for the presence of an interference by molecular ions [59]. For explanatory purposes, Figure 2 reports the behavior of the ionic signal of the ${ }^{52} \mathrm{Cr}^{+}$ion at variations of the He flow. This behavior is similar to those observed for the remaining elements determined in KED mode.

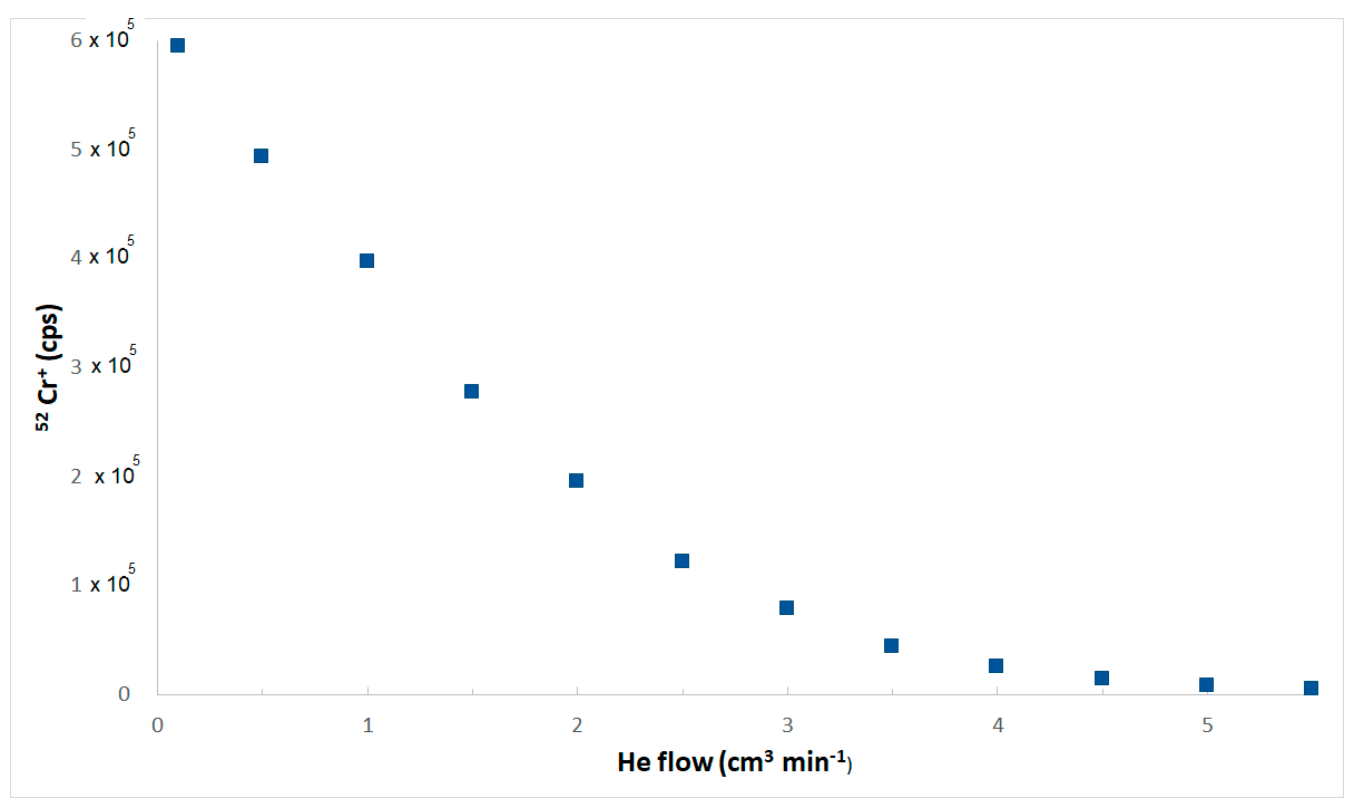

Figure 2. Dependence of the ionic signal of the ${ }^{52} \mathrm{Cr}^{+}$ion at variations of the He flow.

It is evident that the first linear tract of the curve (He flow up to $2 \mathrm{~cm}^{3} \mathrm{~min}^{-1}$ ) gives an account for the removal of the molecular ionic interference, likely due to the ${ }^{40} \mathrm{Ar}^{12} \mathrm{C}^{+}$ ion, whereas the second linear tract of the curve (roughly parallel to the $x$-axis, He flows higher than $4 \mathrm{~cm}^{3} \mathrm{~min}^{-1}$ ) accounts for a slight reduction of signal of the elemental ion as a function of the increase of the He flow. The abscissa of the intersection among both linear plots provided the optimized He flow aimed to remove the interference, which has been observed for 14 elements out 23. Hence, while the number of ionic counts of B, Be, Bi, Li, $\mathrm{Hg}, \mathrm{Mo}, \mathrm{Pb}, \mathrm{Tl}$, and $\mathrm{U}$ was measured in normal mode, the bias from polyatomic ions has been minimized for the remaining elements, using He flows between $3 \mathrm{~cm}^{3} \mathrm{~min}^{-1}$ and $4 \mathrm{~cm}^{3} \min ^{-1}$.

\subsubsection{Quantification, Quality Assurance and Quality Control}

Both external and internal calibration approaches have been used in this study. External calibration (using either analyte standard solutions dissolved in water or in a synthetic matrix, henceforward called SM, formed by $54 \%$ of PG, $43 \%$ of VG, and $3 \%$ of water, respectively) has always been used for all pre-treatments chosen (dilution or microwave-assisted mineralization), but the ascertainment of a severe matrix effect in the quantification of almost all elements suggested the use of the internal calibration, accomplished by means of multiple additions of standard solutions. Figure 3 reports the linear calibration plots obtained using both external and internal calibration for the determination of As.

Constant and proportional bias due to matrix effects are well evident by the comparison of the behaviors of the two external calibration plots (obtained either on a $2 \%(v / v) \mathrm{HNO}_{3}$ solution in water, line 1 , or on a $2 \%(v / v) \mathrm{HNO}_{3}$ solution in $\mathrm{SM}$, line 2 ) and of the three internal calibration plots, obtained on tobacco, tonic, and fruity flavors, respectively. A similar behavior is also evident for the remaining elements quantified. It is well known that the internal calibration method has evident disadvantages with respect 
to the external calibration method. Firstly, it is cumbersome and quite time-consuming, since it requires the preparation of calibration curves for each individual sample and the relevant blanks [60]. In addition, it is characterized by a very high uncertainty, due to the widening of the confidence range of the internal calibration plot [61]. Conversely, its careful execution can almost suppress any matrix interferences, allowing the obtainment of a basically bias-free measurement [62]. A $10 \mu \mathrm{g} \mathrm{dm}{ }^{-3}$ solution of $\mathrm{Rh}$ was used as an internal standard to compensate for any possible signal instability, while a washing cycle of at least $80 \mathrm{~s}$ was interposed between two consecutive samples to eliminate any possible memory effect. All data have been blank-corrected. In order to constantly monitor the overall level of accuracy of the method, one reagent blank every five samples was analyzed, whereas a standard solution containing $0.1 \mu \mathrm{g} \mathrm{kg}^{-1}$ of $\mathrm{Be}, \mathrm{Bi}, \mathrm{Cd}, \mathrm{Co}, \mathrm{Tl}$, and $\mathrm{U}, 1 \mu \mathrm{g} \mathrm{kg}{ }^{-1}$ of $\mathrm{Li}, \mathrm{Pb}, \mathrm{Sb}$, and $\mathrm{Se}, 10 \mu \mathrm{g} \mathrm{kg}{ }^{-1}$ of $\mathrm{As}, \mathrm{Al}, \mathrm{Cu}$, and $\mathrm{Mn}, 50 \mu \mathrm{g} \mathrm{kg}-1$ of $\mathrm{B}, \mathrm{Ba}, \mathrm{Cr}$, and $\mathrm{Hg}$, and $100 \mu \mathrm{g} \mathrm{kg}^{-1}$ of $\mathrm{Fe}, \mathrm{Mo}, \mathrm{Ni}, \mathrm{Sn}$, and $\mathrm{Zn}$ in SM was analyzed every ten samples. Each sample was analyzed in duplicate, and each piece of analytical data is the average of four replicated ICP-MS measurements.

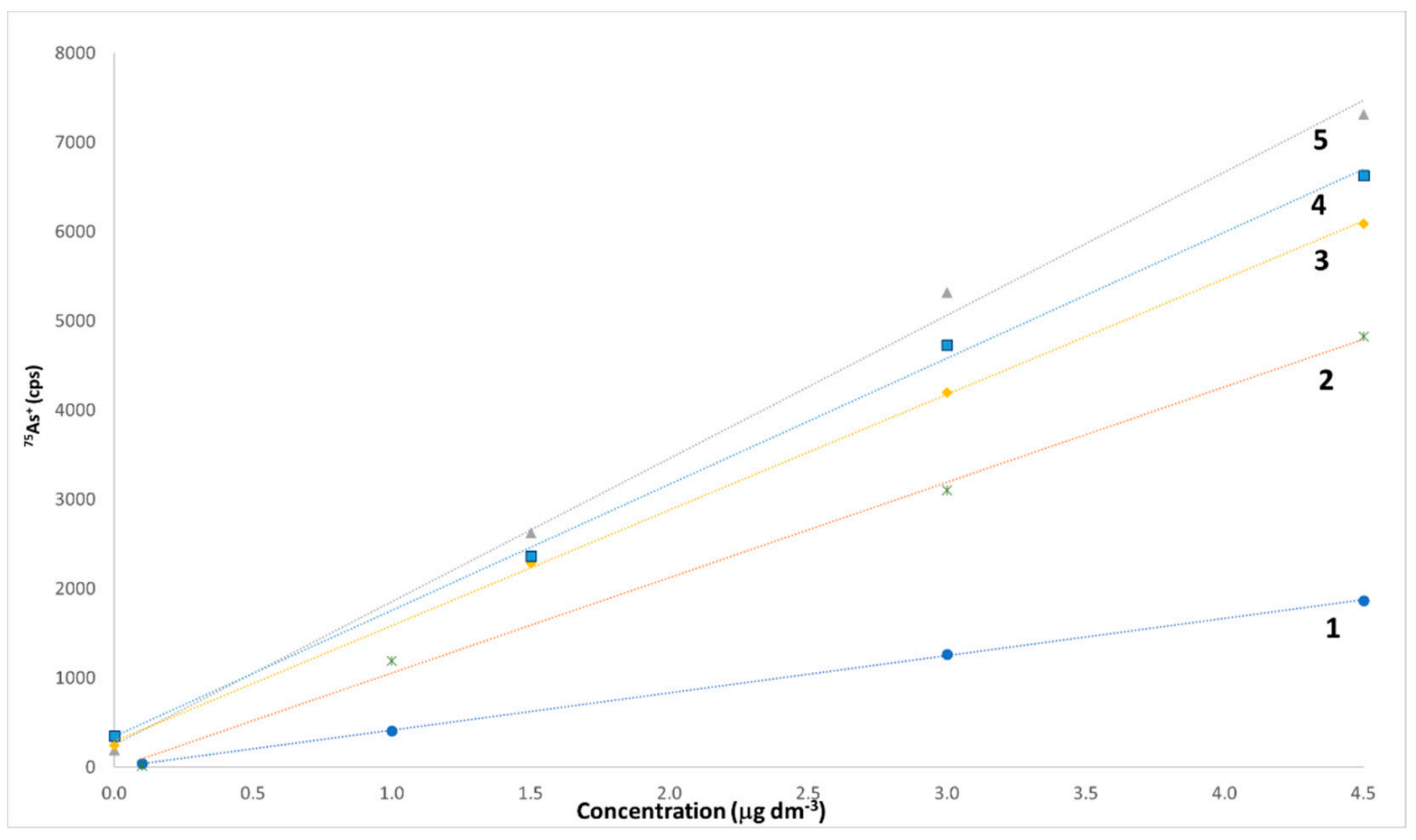

Figure 3. Linear calibration plots obtained using both external and internal calibration for the determination of As. Line 1, external calibration, As concentration in the range between 0.1 and $4.5 \mu \mathrm{g} \mathrm{dm}^{-3}$ in $2 \%(v / v) \mathrm{HNO}_{3}$ in water; line 2, external calibration, As concentration in the range between 0.1 and $4.5 \mu \mathrm{g} \mathrm{dm}^{-3}$ in $2 \%(v / v) \mathrm{HNO}_{3}$ in synthetic matrix; line 3, internal calibration for a tobacco flavor sample; line 4, internal calibration for a tonic flavor sample; line 5, internal calibration for a fruity flavor sample. In calibration lines 3-5, the amounts of As added to samples are of $113 \mathrm{pg}$, $226 \mathrm{pg}$, and $339 \mathrm{pg}$, respectively.

\subsection{Validation}

Validation was performed in terms of Limit of Detection (LoD), Limit of Quantification (LoQ), and precision. Table 2 reports the relevant figures for all the parameters evaluated. 
Table 2. Validation parameters for the ICP-MS determination of the total amount of 23 toxic elements and oligoelements in e-liquids.

\begin{tabular}{|c|c|c|c|c|c|c|c|}
\hline Element & $\begin{array}{c}\text { LoD } \\
\left(\mu \mathrm{g} \mathrm{kg}^{-1}\right)\end{array}$ & $\begin{array}{c}\text { LoQ } \\
\left(\mu \mathrm{g} \mathrm{kg}^{-1}\right)\end{array}$ & $\begin{array}{l}\text { Repeatability } \\
\text { (CV\%) }\end{array}$ & Element & $\begin{array}{c}\text { LoD } \\
\left(\mu \mathrm{g} \mathrm{kg}^{-1}\right)\end{array}$ & $\begin{array}{c}\text { LoQ } \\
\left(\mu \mathrm{g} \mathrm{kg}^{-1}\right)\end{array}$ & $\begin{array}{l}\text { Repeatability } \\
\text { (CV\%) }\end{array}$ \\
\hline $\mathrm{Al}$ & 26 & 84 & 10 & $\mathrm{Li}$ & 0.37 & 1.2 & 40 \\
\hline As & 0.51 & 1.7 & 40 & $\mathrm{Mn}$ & 1.6 & 5.1 & 40 \\
\hline B & 37 & 120 & 60 & Mo & 0.45 & 1.5 & 70 \\
\hline $\mathrm{Ba}$ & 15 & 50 & 30 & $\mathrm{Ni}$ & 2.3 & 7.4 & 60 \\
\hline $\mathrm{Be}$ & 0.057 & 0.19 & 70 & $\mathrm{~Pb}$ & 0.80 & 2.7 & 40 \\
\hline $\mathrm{Bi}$ & 0.089 & 0.29 & 80 & $\mathrm{Sb}$ & 1.1 & 3.7 & 50 \\
\hline $\mathrm{Cd}$ & 0.12 & 0.39 & 90 & Se & 4.6 & 15 & 100 \\
\hline Co & 0.089 & 0.29 & 60 & Sn & 0.24 & 0.78 & 30 \\
\hline $\mathrm{Cr}$ & 4.2 & 14 & 70 & $\mathrm{Tl}$ & 0.055 & 0.18 & 50 \\
\hline $\mathrm{Cu}$ & 5.2 & 17 & 100 & $\mathrm{U}$ & 0.21 & 0.69 & 30 \\
\hline $\mathrm{Fe}$ & 53 & 180 & 90 & $\mathrm{Zn}$ & 62 & 200 & 30 \\
\hline $\mathrm{Hg}$ & 4.5 & 15 & 90 & & & & \\
\hline
\end{tabular}

LoD and LoQ have been calculated according to Currie [63]. The standard deviation needed for the calculation of the $\operatorname{LoD}$ (and, hence, also for the LoQ) was calculated on the repeated measurement of 15 blanks. At last, for the elements previously measured in eliquids, the data obtained are comparable with those reported in the literature [25,36,41,42]. Precision has been measured in terms of repeatability, twice quantifying the same real sample along the whole analytical process in the same analytical session by means of an internal calibration method (multiple standard addition). Quite high CV\% values have been obtained for all parameters, ranging between 10\% (for $\mathrm{Al}$ ) and $100 \%$ (for $\mathrm{Cu}$ and $\mathrm{Se}$ ). Since Se has always been found below its LoD for all samples of e-liquids, the precision was evaluated for this element by spiking the samples with the amount of Se standard solution needed to reach a final concentration in the samples slightly over the LoQ (i.e., $15 \mu \mathrm{g} \mathrm{kg}{ }^{-1}$ ). Regardless, it is well known that, for the peculiar features of the standard addition method, the precision parameters measured that work in this way are much worse than those measured by quantifying by external calibration [61]. Trueness is usually measured by (i) analyzing a certified reference material (CRM), (ii) by comparison with an independent and validated analytical method, or, ultimately, (iii) with recovery tests, performed by spiking the sample with repeated amounts of pure analyte. Unfortunately, none of these methods can be used in this case. To the best of our knowledge, no CRM of e-liquids is commercially available, and the heavy matrix effect observed in this study, well substantiated in Figure 3 , discourages using any apparently "similar" matrix. In addition, no independent and validated analytical method capable of measuring the concentration of 23 elements at concentrations no higher than a few $\mu \mathrm{g} \mathrm{dm}^{-3}$ is currently available in our labs. Finally, the close similarities among the application of both the standard addition method and the recovery tests based on spiked samples suggest also discarding this option. In the attempt to obtain a tentative evaluation of the trueness of the method, a "synthetic e-liquid" was prepared, where known amounts of each analyte were added to the SM solution to reach a concentration close to the average value measured for the real samples. For the analytes that were not frequently quantified, their final concentration in the synthetic e-liquid was the LoQ. Multiple spiking tests, performed on this sample, allowed the obtainment of recoveries between $81 \%$ (for $\mathrm{Cr}$ ) and $118 \%$ (for $\mathrm{Zn}$ ), exhibiting hence a negligible level of bias if compared to the very low level of concentration measured.

\subsection{Concentration of 23 Elements in 37 e-Liquids}

The data relative to the determination of the amount of 23 elements in 37 e-liquids belonging to three main flavors (i.e., fruity, tobacco, and tonic) are summarized, in terms of both mean and ranges, in Table 3. 
Table 3. Mean amounts, ranges (both in $\mu \mathrm{g} \mathrm{kg}^{-1}$ ), and percentage of quantified samples $(\mathrm{C}>\mathrm{LoQ})$ in the determination of 23 toxic elements and oligoelements in 37 different e-liquids.

\begin{tabular}{|c|c|c|c|c|c|c|c|c|}
\hline \multirow{2}{*}{$\begin{array}{c}\text { Elements } \\
\mathrm{Al}\end{array}$} & \multicolumn{2}{|c|}{$\begin{array}{l}\text { All Flavors }(n=37) \\
\quad \text { Mean; Range; } \\
\% \text { Samples > LoQ) }\end{array}$} & \multicolumn{2}{|c|}{$\begin{array}{c}\text { Fruity Flavors }(n=9) \\
\text { (Mean; Range; } \\
\% \text { Samples > LoQ) }\end{array}$} & \multicolumn{2}{|c|}{$\begin{array}{c}\text { Tobacco Flavors }(n=16) \\
\text { (Mean; Range; } \\
\text { \% Samples > LoQ) }\end{array}$} & \multicolumn{2}{|c|}{$\begin{array}{c}\text { Tonic Flavors }(n=12) \\
\text { (Mean; Range; } \\
\% \text { Samples > LoQ) }\end{array}$} \\
\hline & $<33 ;<26-160$ & $8 \%$ & $<35 ;<26-110$ & $11 \%$ & $<37 ;<26-160$ & $13 \%$ & $<26 ;<26 ;<26$ & $0 \%$ \\
\hline As & $5 ; 0.6-11$ & $100 \%$ & $6 ; 0.6-8$ & $100 \%$ & $5 ; 1.5-11$ & $100 \%$ & $6 ; \underline{0.8}-10$ & $100 \%$ \\
\hline $\mathrm{B}$ & $\leq 61 ;<37-140$ & $54 \%$ & $\leq 50 ; \overline{37}-100$ & $\underline{33 \%}$ & $\leq 60 ;<37-100$ & $\underline{56 \%}$ & 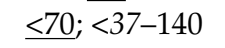 & $67 \%$ \\
\hline $\mathrm{Ba}$ & $\leq 27 ;<15-130$ & $62 \%$ & $<55 ;<15-\overline{130}$ & $\overline{78 \%}$ & $<20 ;<15-\underline{45}$ & $63 \%$ & $\overrightarrow{<18} ;<15-\underline{30}$ & $50 \%$ \\
\hline $\mathrm{Be}$ & $\begin{array}{c}<0.06 \\
<0.057-0.12\end{array}$ & $14 \%$ & $\begin{array}{c}<0.07 \\
<0.057-0.12\end{array}$ & $33 \%$ & $\begin{array}{c}<0.058 ; \\
<0.057-0.06\end{array}$ & $13 \%$ & $\begin{array}{c}<0.057 ; \\
<0.057-<0.057\end{array}$ & $0 \%$ \\
\hline $\mathrm{Bi}$ & $<\frac{<0.1 \overline{1} ;}{<0.089-0.3}$ & $27 \%$ & $\begin{array}{c}<0.09 ; \\
<0.089-0.1\end{array}$ & $11 \%$ & $\begin{array}{c}<0.1 \overline{4} ; \\
<0.089-0.3\end{array}$ & $56 \%$ & $\begin{array}{c}<0.089 \\
<0.089-<0.089\end{array}$ & $0 \%$ \\
\hline $\mathrm{Cd}$ & $\leq 0.14 ;<0.12-\underline{1}$ & $5 \%$ & $\begin{array}{c}<0.12 ; \\
<0.12-<0.12\end{array}$ & $0 \%$ & $\leq 0.18 ;<0.12-1$ & $6 \%$ & $\begin{array}{c}<0.12 ; \\
<0.12-0.13\end{array}$ & $8 \%$ \\
\hline Co & $\begin{array}{c}<0.34 \\
<0.089-0.9\end{array}$ & $84 \%$ & $\begin{array}{c}<0.3 \\
<0.089-0.9\end{array}$ & $78 \%$ & $<0.4 ; 0.1-0.8$ & $100 \%$ & $\begin{array}{c}<0 . \overline{3} \\
<0.089-0.6\end{array}$ & $67 \%$ \\
\hline $\mathrm{Cr}$ & $34 ; 20-40$ & $100 \%$ & $38 ; 30-40$ & $100 \%$ & $34 ; 30-40$ & $100 \%$ & $32 ; 20-40$ & $100 \%$ \\
\hline $\mathrm{Cu}$ & $\leq 7.1 ;<5.2-20$ & $41 \%$ & $\leq 10 ;<5.2-20$ & $56 \%$ & $\leq 7 ;<5.2-\underline{14}$ & $50 \%$ & $\leq 5.4 ;<5.2-\underline{7}$ & $17 \%$ \\
\hline $\mathrm{Fe}$ & $<\overline{308} ;<53-3000$ & $65 \%$ & $\overline{\leq 66} ;<53-100$ & $56 \%$ & $<\overline{570} ;<53-\overline{3000}$ & $88 \%$ & $\leq \overline{140 ;}<<53-1000$ & $42 \%$ \\
\hline $\mathrm{Hg}$ & $\leq \underline{5} ;<4.5-\underline{14}$ & $8 \%$ & $\overline{\leq 5} ;<4.5-\overline{10}$ & $11 \%$ & $\leq 5 ;<4.5-\underline{14}$ & $6 \%$ & $\overline{\leq 5} ;<4.5-\underline{5}$ & $8 \%$ \\
\hline $\mathrm{Li}$ & $\overline{1} .9 ; 0.7-\overline{9}$ & $100 \%$ & $\overline{1.5} ; \underline{0.8}-\overline{2}$ & $100 \%$ & $\overline{2.5} ; 0.9-\overline{9}$ & $100 \%$ & $\overline{1.5} ; \underline{0.7-2 . \overline{2}}$ & $100 \%$ \\
\hline Mn & $<10 ;<\overline{1.6}-80$ & $73 \%$ & $\leq 2 ;<1.6-\underline{4}$ & $67 \%$ & $<18 ;<1.6-80$ & $69 \%$ & $\leq 5 ;<1.6-20$ & $83 \%$ \\
\hline Mo & $\leq 0.8 ;<0.45-3$ & $57 \%$ & $\leq \overline{0.6} ;<0.45-\underline{1}$ & $44 \%$ & $\leq 1 ;<0.45-3$ & $81 \%$ & $\leq 0.7 ;<0.45-2$ & $33 \%$ \\
\hline $\mathrm{Ni}$ & $<3.5 ;<2.3-14$ & $46 \%$ & $\overline{<3.4} ;<2.3-\underline{7}$ & $67 \%$ & $<3.8 ;<2.3-14$ & $44 \%$ & $<3.2 ;<2.3-\underline{6}$ & $33 \%$ \\
\hline $\mathrm{Pb}$ & $<1.0 ;<0.8-3$ & $19 \%$ & $<1.4 ;<0.8-\overline{3}$ & $44 \%$ & $<0.84 ;<0.8-1.3$ & $13 \%$ & $<0.81 ;<0.8-1$ & $8 \%$ \\
\hline $\mathrm{Sb}$ & $\overline{<2.9} ;<1.1-10$ & $73 \%$ & $\overline{<1.8} ;<1.1-4$ & $78 \%$ & $\leq 3.1 ;<1.1-7$ & $75 \%$ & $<3.4 ;<1.1-10$ & $67 \%$ \\
\hline Se & $<\overline{4.6} ;<4.6-<4.6$ & $0 \%$ & $<\overline{4.6} ;<4.6-<4.6$ & $0 \%$ & $<\overline{4.6 ;}<4.6-<4.6$ & $0 \%$ & $\overline{<4.6} ;<4.6-<4.6$ & $0 \%$ \\
\hline Sn & $\leq 0.6 ;<0.24-4$ & $65 \%$ & $<1 ;<0.24-4$ & $67 \%$ & $\leq 0.5 ;<0.24-1.6$ & $81 \%$ & $\begin{array}{c}<0.37 \\
<0.24-1.5\end{array}$ & $42 \%$ \\
\hline $\mathrm{Tl}$ & 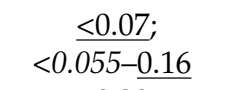 & $46 \%$ & $\begin{array}{c}<0.07 ; \\
<0.055-\underline{0.16}\end{array}$ & $22 \%$ & $\begin{array}{c}<0.06 ; \\
<0.055-\underline{0.15}\end{array}$ & $38 \%$ & $<\frac{<0.08}{<0.055-0.15}$ & $75 \%$ \\
\hline $\mathrm{U}$ & $\begin{array}{l}<0.29 ; \\
<0.21-0.7\end{array}$ & $41 \%$ & $\begin{array}{c}<0.29 ; \\
<0.21-\underline{0.6}\end{array}$ & $44 \%$ & $\begin{array}{c}<0.3 \overline{1} ; \\
<0.21-0.6\end{array}$ & $44 \%$ & $<\frac{<0.2 \overline{6}}{<0.21-0.7}$ & $33 \%$ \\
\hline $\mathrm{Zn}$ & $\leq 109 ;<62-300$ & $76 \%$ & $\leq 150 ;<62 \overline{-300}$ & $89 \%$ & $\leq 90 ;<62 \overline{-220}$ & $63 \%$ & $\leq 100 ;<62-\underline{170}$ & $83 \%$ \\
\hline
\end{tabular}

Each sample has been analyzed twice. In italics: data below the LoD; in underlined: data below the LoQ. All average data have been rounded after calculation. The average data prefixed with the sign "<" have been calculated based on at least one concentration that has been found below the corresponding LoD.

The data reported in Table 3 show that all e-liquids considered exhibit a very low amount of the evaluated analytes, being only ca. $0.6 \mathrm{mg} \mathrm{kg}^{-1}$, the sum of their average concentrations measured in this study. These amounts are comparable with the literature data $[25,36,41]$ and confirm that the amount of potentially toxic elements contained in e-devices is orders of magnitude less than in traditional cigarettes [44,45]. Among all elements considered, only Se has always been found below its LoD in all samples analyzed. This is not surprising, knowing the scarce sensitivity of Se in terms of counts per second as a function of its concentration [59]. In addition, the mineralization process implies a dilution of 50 times of the sample, hence the effective LoD for mineralized solutions is $92 \mathrm{ng} \mathrm{dm}^{-3}$, i.e., quite close to the instrumental detection limit [64]. As far as the remaining elements are concerned, only six elements out of 36 (i.e., As, $\mathrm{Co}, \mathrm{Cr}, \mathrm{Fe}, \mathrm{Li}$, and $\mathrm{Mn}$ ) exhibit a mean concentration higher than the LoQ. Only three elements, i.e., As, $\mathrm{Cr}$, and $\mathrm{Li}$, are always quantified (100\% of the samples), but none of them seem to represent an effective health threat for vapers. Indeed, the highest amount measured for these elements is $11 \mu \mathrm{g} \mathrm{kg}^{-1}$ for As and $40 \mu \mathrm{g} \mathrm{kg}^{-1}$ for Cr. Only for the sake of comparison, the limits posed by the EU guidelines for these elements in water intended for human use are $10 \mu \mathrm{g} \mathrm{kg}^{-1}$ for As and $50 \mu \mathrm{g} \mathrm{kg}^{-1}$ for Cr, respectively [65], whereas the amount of daily intake for humans of water is, obviously, several orders of magnitude higher than that of e-liquids. Additionally, $\mathrm{Li}$ is less abundant than $\mathrm{As}$ and $\mathrm{Cr}$, and its average concentration is only 
$1.9 \mu \mathrm{g} \mathrm{kg}^{-1}$. The average concentration of the elements most frequently quantified are, in decreasing percentage, Co (average concentration $<0.34 \mu \mathrm{g} \mathrm{kg}^{-1}$, quantified in the $84 \%$ of samples), Zn (<109 $\left.\mu \mathrm{g} \mathrm{kg}^{-1}, 76 \%\right), \mathrm{Mn}\left(<10 \mu \mathrm{g} \mathrm{kg}{ }^{-1}, 73 \%\right), \mathrm{Sb}\left(<2.9 \mu \mathrm{g} \mathrm{kg}^{-1}, 73 \%\right)$, and $\mathrm{Fe}\left(<308 \mu \mathrm{g} \mathrm{kg}^{-1}, 65 \%\right)$. Among the remaining toxic elements, only $\mathrm{Sn}$ and Ba have been quantified in over $25 \%$ of the samples, where the remaining elements, i.e., $\mathrm{Be}, \mathrm{Cd}, \mathrm{Hg}, \mathrm{Pb}$, $\mathrm{Tl}$, and $\mathrm{U}$, had seldom reached the relevant LoQs.

Table 4 reports a comparison between the data (mean and range) here obtained and those reported in the literature. To favor a reliable comparison among data obtained in different studies, only those obtained by using ICP-MS methods have been considered in this table.

Table 4. Average amounts and ranges (in $\mu \mathrm{g} \mathrm{kg}^{-1}$ ) of elements of health concern in e-liquids. Concentration was measured by means of ICP-MS methods.

\begin{tabular}{|c|c|c|c|c|c|c|c|c|}
\hline Elements & $\begin{array}{c}\text { Ref. [25] }{ }^{\mathrm{a}} \\
(n=6)\end{array}$ & $\begin{array}{c}\text { Ref. [33] }^{\mathrm{b}} \\
(n=5)\end{array}$ & $\begin{array}{c}\text { Ref. [36] }^{\mathrm{c}} \\
(n=56)\end{array}$ & $\begin{array}{c}\text { Ref. [37] }^{\mathrm{d}} \\
(n=1)\end{array}$ & $\begin{array}{c}\text { Ref. [41] }^{\mathrm{a}} \\
(n=27)\end{array}$ & $\begin{array}{l}\text { Ref. [42] }^{\mathrm{e}} \\
(n=2)\end{array}$ & $\begin{array}{c}{\text { Ref. }[43]^{\mathrm{f}}}_{(n=3)}\end{array}$ & $\begin{array}{c}\text { This Study } \\
(n=37)\end{array}$ \\
\hline $\mathrm{Al}$ & $12 ; 10-15$ & & $\begin{array}{c}50.3 ; \\
46.22-59.6\end{array}$ & $7.7 \pm 0.5$ & $12.9 ; 8.82-30.7$ & & & $\leq 33 ;<26-160$ \\
\hline As & $1.2 ;<1-1.5$ & & & $0.08 \pm 0.04$ & $1.57 ;<1-3.42$ & $<430$ & $\begin{array}{c}2.18 ; \\
0.83-3.04\end{array}$ & $5 ; \underline{0.6}-11$ \\
\hline $\begin{array}{c}\mathrm{B} \\
\mathrm{Ba}\end{array}$ & & & & & & & & $\begin{array}{l}<61 ;<37-140 \\
<27 ;<15-130\end{array}$ \\
\hline $\mathrm{Be}$ & $<0.1$ & & & & $<0.1$ & & & $\begin{array}{l}<0.06 \\
<0.057-0.12\end{array}$ \\
\hline $\mathrm{Bi}$ & & & & & & & & $<0.0 .1 \overline{1 ;} ;$ \\
\hline $\mathrm{Cd}$ & $<0.4$ & $43.5 ; 0.137-755$ & $<0.1$ & $<0.01$ & $<0.4$ & $<220$ & $\begin{array}{c}0.54 \\
<0.25-1.28\end{array}$ & $\leq 0.14 ;<0.12-\underline{1}$ \\
\hline Co & $\begin{array}{c}0.15 \\
<0.1-0.27\end{array}$ & & & & $0.262 ;<0.1-0.884$ & & & $\begin{array}{c}<0.34 \\
<0.089-0.9\end{array}$ \\
\hline $\mathrm{Cr}$ & $5.2 ; 4.1-7.7$ & $669 ; 41.5-16900$ & $12 ; 12-14.26$ & & $7.16 ; 4.08-11.5$ & & & $34 ; 20-40$ \\
\hline $\mathrm{Cu}$ & $23 ;<20-32$ & & $\begin{array}{c}5.14 \\
<1.0-16.1\end{array}$ & $<0.01$ & $27.0 ;<20-30.6$ & & & $\leq 7.1 ;<5.2-20$ \\
\hline $\mathrm{Fe}$ & & & $\begin{array}{c}66.5 ; \\
48.74-130.9\end{array}$ & $4.1 \pm 0.2$ & & & & $<308 ;<53-3000$ \\
\hline $\begin{array}{r}\mathrm{Hg} \\
\mathrm{Li}\end{array}$ & $<4$ & & & & $4.38 ;<4-4.54$ & & & $\frac{<5 ;<4.5-14}{1.9 ; 0.7-9}$ \\
\hline $\mathrm{Mn}$ & $2.1 ;<1.6-3.3$ & $\begin{array}{c}1627 ; \\
11.8-31500\end{array}$ & $\begin{array}{c}1.09 ; \\
<1.0-2.74\end{array}$ & $0.159 \pm 0.006$ & $3.99 ;<1.6-8.42$ & & & $<10 ;<1.6-80$ \\
\hline Mo & & & & & & & & $\leq 0.8 ;<0.45-3$ \\
\hline $\mathrm{Ni}$ & $<16$ & $\begin{array}{c}7613 ; \\
13.7-72700\end{array}$ & $\begin{array}{c}7.33 \\
5.30-47.4\end{array}$ & $0.161 \pm 0.007$ & $<16$ & & $\begin{array}{c}3.43 \\
1.42-5.11\end{array}$ & $\leq 3.5 ;<2.3-14$ \\
\hline $\mathrm{Pb}$ & $<1$ & $444 ; 3.17-4870$ & $\begin{array}{c}0.476 ; \\
0.243-1.05\end{array}$ & $<0.01$ & $<1$ & & $\begin{array}{c}12.28 \\
<0.25-23.49\end{array}$ & $\leq 1.0 ;<0.8-3$ \\
\hline $\begin{array}{l}\mathrm{Sb} \\
\mathrm{Se}\end{array}$ & $1.6 ; 1.2-1.5$ & & $1.0 ; 1.0-1.219$ & & $7.21 ; 0.400-214$ & & & $\begin{aligned}<2.9 ; & <1.1-10 \\
<4.6 ; & <4.6-<4.6\end{aligned}$ \\
\hline Sn & & & $\begin{array}{c}1.53 \\
0.689-3.75\end{array}$ & & & & & $\leq 0.6 ;<0.24-4$ \\
\hline $\mathrm{Tl}$ & $<0.1$ & & & & $<0.1$ & & & $<\frac{<0.07 ;}{0.055-0.16}$ \\
\hline V & $\begin{array}{c}0.45 \\
<0.4-0.64\end{array}$ & & & & $0.602 ;<0.4-1.36$ & & & - \\
\hline $\mathrm{U}$ & & & & & & & & $\begin{array}{l}<0.29 \\
<0.21-0.7\end{array}$ \\
\hline $\mathrm{Zn}$ & $<200$ & & $\begin{array}{c}18.2 ; \\
11.94-28.2\end{array}$ & $0.51 \pm 0.03$ & $418 ;<200-510$ & & & $\leq 109 ;<62-300$ \\
\hline
\end{tabular}

In italics: data below the LoD; in underlined: data below the LoQ. ${ }^{\text {a }}$ Solvents: $\mathrm{PG}<65 \%$, VG $<35 \%$, samples with $\left(16 \mathrm{mg} \mathrm{cm}^{-3}\right)$ or without nicotine. ${ }^{\mathrm{b}}$ E-liquids were popular brands sold in the USA. An interlaboratory trial confirmed these data. ${ }^{\mathrm{c}}$ Solvents: PG, $70 \%$ VG, $30 \%$. Data are relative to median, where the range is within the 25th and the 75th percentile. Data reported in this column are the sum of those reported in Table 2 of the paper and the amount of the relevant blanks reported in Table S1 of the supplementary material. Data are from only one measurement for each sample. Trueness has been evaluated through an interlaboratory trial and by analysis of a NIST SRM ${ }^{\circledR \circledR}$ 1640a (Trace Elements in Natural Water). ${ }^{\mathrm{d}}$ E-liquid was 1:100 diluted with $\mathrm{HNO}_{3} 1 \%$ in water before ICP-MS analysis. All trace metal analyses were performed as a contracted service. No details were provided on the validation of the ICP-MS method. ${ }^{\mathrm{e}}$ MarkTen ${ }^{\circledR \circledR}$ Menthol and Classic e-liquids, both containing 1.5\% nicotine. No details were provided on the validation of the ICP-MS method. ${ }^{\mathrm{f}}$ No details were provided on the nature and validation of the ICP-MS determination. 
Among the literature contributions considered in Table 4, V is the only element not analyzed in this study, but it previously was quantified by Beauval et al. [25,41]. Conversely, the amounts of $\mathrm{B}, \mathrm{Ba}, \mathrm{Bi}, \mathrm{Li}, \mathrm{Mo}$, and $\mathrm{U}$ in e-liquids were measured for the first time in this study. Another element never quantified in previous studies, i.e., Se, was found to be below its LoD in this research. The amounts of elements analyzed in this study are in good agreement with results reported using validated methods for the determination of several elements in a statistically significant number of samples $[25,36,41]$. The most important differences regard the most abundant (and the most interfered) elements, such as $\mathrm{Al}, \mathrm{Fe}$, and $\mathrm{Zn}$, which were frequently present in higher concentrations in this study. On the other hand, the amounts of another "critical" element, such as $\mathrm{Ni}$, are higher in the literature studies than in this research. For elements such as $\mathrm{As}, \mathrm{Cd}, \mathrm{Ni}$, and $\mathrm{Pb}$, data here reported are in fair agreement with those reported by Song et al. [43], even if the validation of the method used in that contribution was not reported in the paper. On the whole, and with only very rare exceptions, such as the quite high amounts of $\mathrm{Sb}$ in a few of the e-liquids measured by Beauval et al. [41], the amounts of toxic elements found in e-liquids in this, as well as in previous studies [25,36,37,41-43], are coherent with a negligible health risk associated to its intake by vapers. The data measured here are several orders of magnitude below the worrying amounts measured by Hess et al. [33] for $\mathrm{Cd}, \mathrm{Cu}, \mathrm{Mn}, \mathrm{Ni}$, and $\mathrm{Pb}$ in two of the most popular brands of e-liquids sold in the USA. On the other hand, these concentrations, albeit much higher than those measured in the cited literature studies, are within the amounts recommended by the AFNOR [52], i.e., $1 \mathrm{mg} \mathrm{kg}^{-1}$ for $\mathrm{Cd}$ and $\mathrm{Hg}$, $3 \mathrm{mg} \mathrm{kg}^{-1}$ for As, $5 \mathrm{mg} \mathrm{kg}^{-1}$ for $\mathrm{Sb}$, and $10 \mathrm{mg} \mathrm{kg}^{-1}$ for $\mathrm{Pb}$.

Data reported also account for some differences among the three classes of flavors. Figure 4 shows the box-whisker plots for the concentrations of the most representative elements under exam in nine fruity, sixteen tobacco, and twelve tonic e-liquids. As a general behavior, tobacco flavors are the richest in the considered elements, whereas tonic flavors are the less abundant. In particular, tobacco flavors exhibit the highest amounts of $\mathrm{Al}, \mathrm{Bi}, \mathrm{Cd}, \mathrm{Fe}, \mathrm{Hg}, \mathrm{Li}, \mathrm{Mn}, \mathrm{Mo}$, and $\mathrm{Ni}$, whereas the amounts of $\mathrm{Al}, \mathrm{Be}, \mathrm{Bi}$, and $\mathrm{Cd}$ are always below the relevant LoDs in tonic flavors. Interestingly, fruity flavors show the highest amounts of some bivalent elements such as $\mathrm{Ba}, \mathrm{Be}, \mathrm{Cu}, \mathrm{Pb}, \mathrm{Sn}$, and $\mathrm{Zn}$.

\subsection{Concentration of 23 Elements in PG, VG, Water, and Nicotine Used in the Composition of the e-Liquids}

Table 5 reports the concentration of the 23 elements under exam in all the compounds used for the preparation of the e-liquids, with the only exclusion being of the concentrated flavor, always present in a $10 \%(w / w)$ amount in the final composition of the e-liquid.

Organic samples were analyzed using the same method developed for e-liquids, whereas water was analyzed using literature official methods $[66,67]$. The data reported in Table 5 give an account for an overall negligible contribution of toxic elements in the composition of the e-liquids. On the other hand, it is evident that the most abundant elements in e-liquids come from VG (i.e., As, $\mathrm{Cr}, \mathrm{Cu}, \mathrm{Li}$, and $\mathrm{Zn}$ ) and PG (i.e., B, Cr, Fe, and $\mathrm{Zn}$ ). Furthermore, the water is quite rich in $\mathrm{B}$, whereas nicotine (always absent in all the samples analyzed, see Section 3.1) is very rich in $\mathrm{Al}\left(5 \mathrm{mg} \mathrm{kg}^{-1}\right)$. Moreover, the amounts of $\mathrm{Cr}, \mathrm{Zn}$, and $\mathrm{Sb}$ are significant. Since the concentration of $\mathrm{Cr}$ is relatively elevated in both VG and PG, it is likely that the high amount of this element measured in the aerosols can depend not only on the metal constituents of the e-cigarette, but also on the aliquot of $\mathrm{Cr}$ present in the organic solvents in the e-liquids. Hence, a reduction of the elemental concentrations of the main trace elements contained in the e-liquids would be an effective tool to further reduce the amount of oligoelements in them.

\subsection{Principal Components Analysis}

In order to verify which elements were deriving either from the constituents or from the flavors, the whole dataset consisting of 37 samples of e-liquids and 22 elements (Se was always found below its LoD and thus excluded) was normalized with respect to the concentration of each element measured in the SM (i.e., in the absence of any contribution 
given by any flavor), obtaining a dataset expressed in terms of standard deviation referred to in the SM concentration. A principal components analysis (PCA) was carried out on the normalized dataset. Figure 5 shows the loading plot (a), with its zoomed view (b), and the score plot (c), with its zoomed view (d).
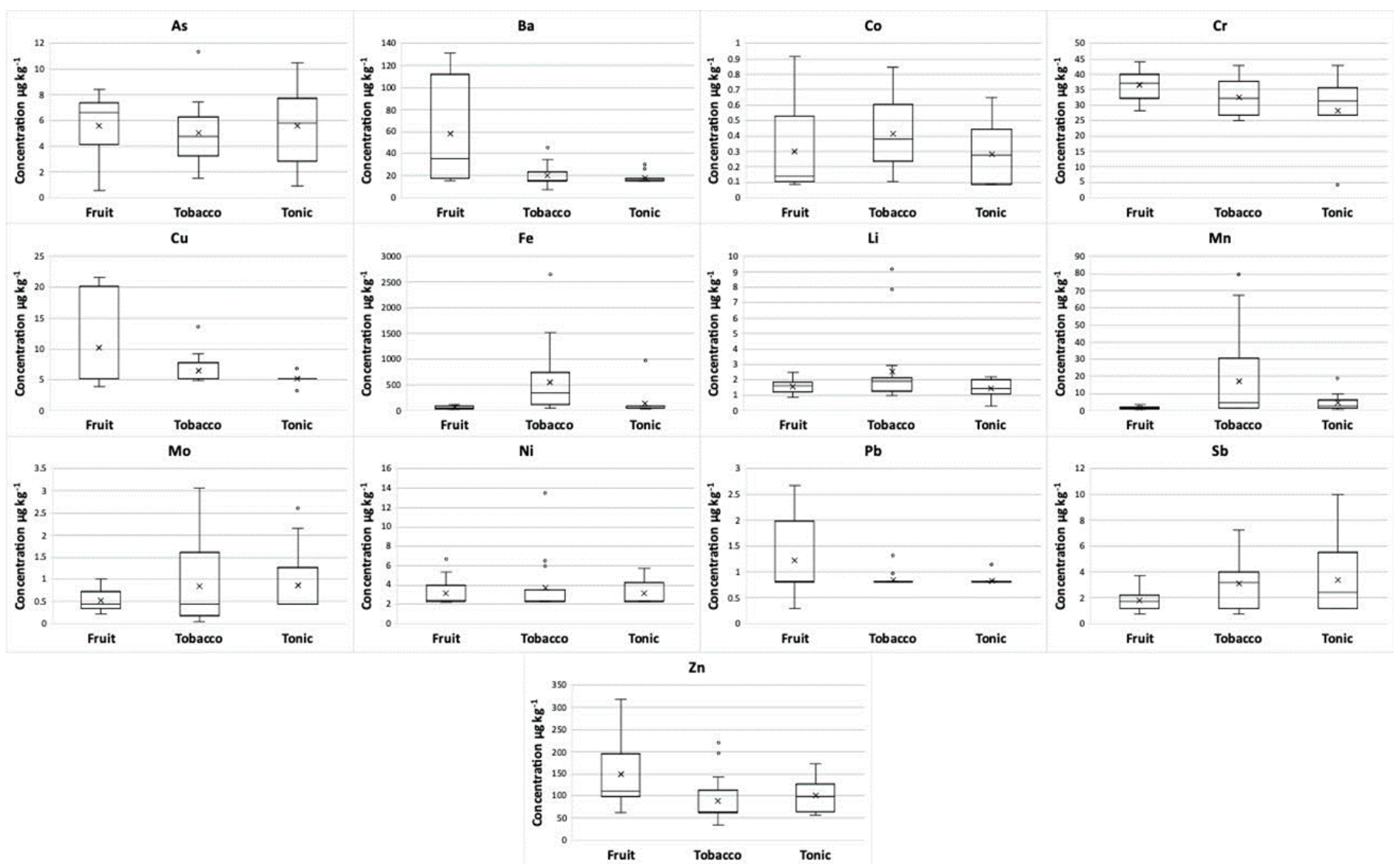

Figure 4. Box-whisker plots of the concentrations of $\mathrm{As}, \mathrm{Ba}, \mathrm{Co}, \mathrm{Cr}, \mathrm{Cu}, \mathrm{Fe}, \mathrm{Li}, \mathrm{Mn}, \mathrm{Mo}, \mathrm{Ni}, \mathrm{Pb}, \mathrm{Sb}$, and $\mathrm{Zn}$ in the three different flavor classes of e-liquids. The horizontal lines in the box represent the 25 th percentile, the mean value, and the 75th percentile, respectively, and the interval between the ends of the whiskers represents the range. The " $x$ " symbol is the median value, and the "。" symbol represents the outlier amounts.

Table 5. Mean amounts (in $\mu \mathrm{g} \mathrm{kg} \mathrm{kg}^{-1} \pm \mathrm{SD}$ ) of 23 toxic elements and oligoelements in VG, PG, water, and nicotine used for the preparation of the e-liquids. $n=3$.

\begin{tabular}{ccccc}
\hline Element & VG & PG & Water & Nicotine \\
\hline $\mathrm{Al}$ & $<26$ & $<26$ & $<5$ & $5000 \pm 1000$ \\
$\mathrm{As}$ & $7 \pm 2$ & $2.6 \pm 0.6$ & $0.020 \pm 0.005$ & $0.8 \pm 0.2$ \\
$\mathrm{~B}$ & $<37$ & $110 \pm 10$ & $470 \pm 70$ & $<37$ \\
$\mathrm{Ba}$ & $<15$ & $<15$ & $0.18 \pm 0.02$ & $<15$ \\
$\mathrm{Be}$ & $<0.057$ & $<0.057$ & $<0.01$ & $<0.057$ \\
$\mathrm{Bi}$ & $<0.089$ & $<0.089$ & $<.005$ & $<0.089$ \\
$\mathrm{Cd}$ & $<0.12$ & $<0.12$ & $<0.005$ & $<0.12$ \\
$\mathrm{Co}$ & $0.2 \pm 0.1$ & $49 \pm 6$ & $<0.1$ & $<0.089$ \\
$\mathrm{Cr}$ & $56 \pm 7$ & $<5.2$ & $<0.1$ & $<9 \pm 8$ \\
$\mathrm{Cu}$ & $22 \pm 4$ & $100 \pm 20$ & $<1$ & $<5.2$ \\
$\mathrm{Fe}$ & $0.6 \pm 0.1$ & $<4.5$ & $<0.005$ & $0.6 \pm 0.1$ \\
$\mathrm{Hg}$ & $<4.5$ & $<0.37$ & $0.374 \pm 0.001$ & $<4.5$ \\
$\mathrm{Li}$ & $6 \pm 1$ & $<1.6$ & $2.8 \pm 0.2$ & $<1.2$ \\
$\mathrm{Mn}$ & $<1.6$ & $<0.45$ & $0.8 \pm 0.2$ & $11 \pm 2$ \\
$\mathrm{Mo}$ & $<0.45$ & & $<0.45$ \\
\end{tabular}


Table 5. Cont.

\begin{tabular}{ccccc}
\hline Element & VG & PG & Water & Nicotine \\
\hline $\mathrm{Ni}$ & $<2.3$ & $<2.3$ & $2.5 \pm 0.6$ & $<2.3$ \\
$\mathrm{~Pb}$ & $<0.80$ & $<0.80$ & $1.6 \pm 0.1$ & $<0.80$ \\
$\mathrm{Sb}$ & $<3.7$ & $<1.1$ & $0.67 \pm 0.01$ & $120 \pm 20$ \\
$\mathrm{Se}$ & $<4.6$ & $<4.6$ & $0.035 \pm 0.015$ & $<4.6$ \\
$\mathrm{Sn}$ & $<0.24$ & $<0.24$ & $<0.01$ & $<0.24$ \\
$\mathrm{Tl}$ & $<0.18$ & $<0.055$ & $<0.001$ & $<0.055$ \\
$\mathrm{U}$ & $<0.21$ & $<0.21$ & $<0.003$ & $<0.21$ \\
$\mathrm{Zn}$ & $180 \pm 40$ & $41 \pm 9$ & $5 \pm 1$ & $160 \pm 30$ \\
\hline
\end{tabular}

VG: vegetal glycerin; PG: propylene glycol; SD: standard deviation; in italics: amounts below the LoD; underlined: amounts below the LoQ.
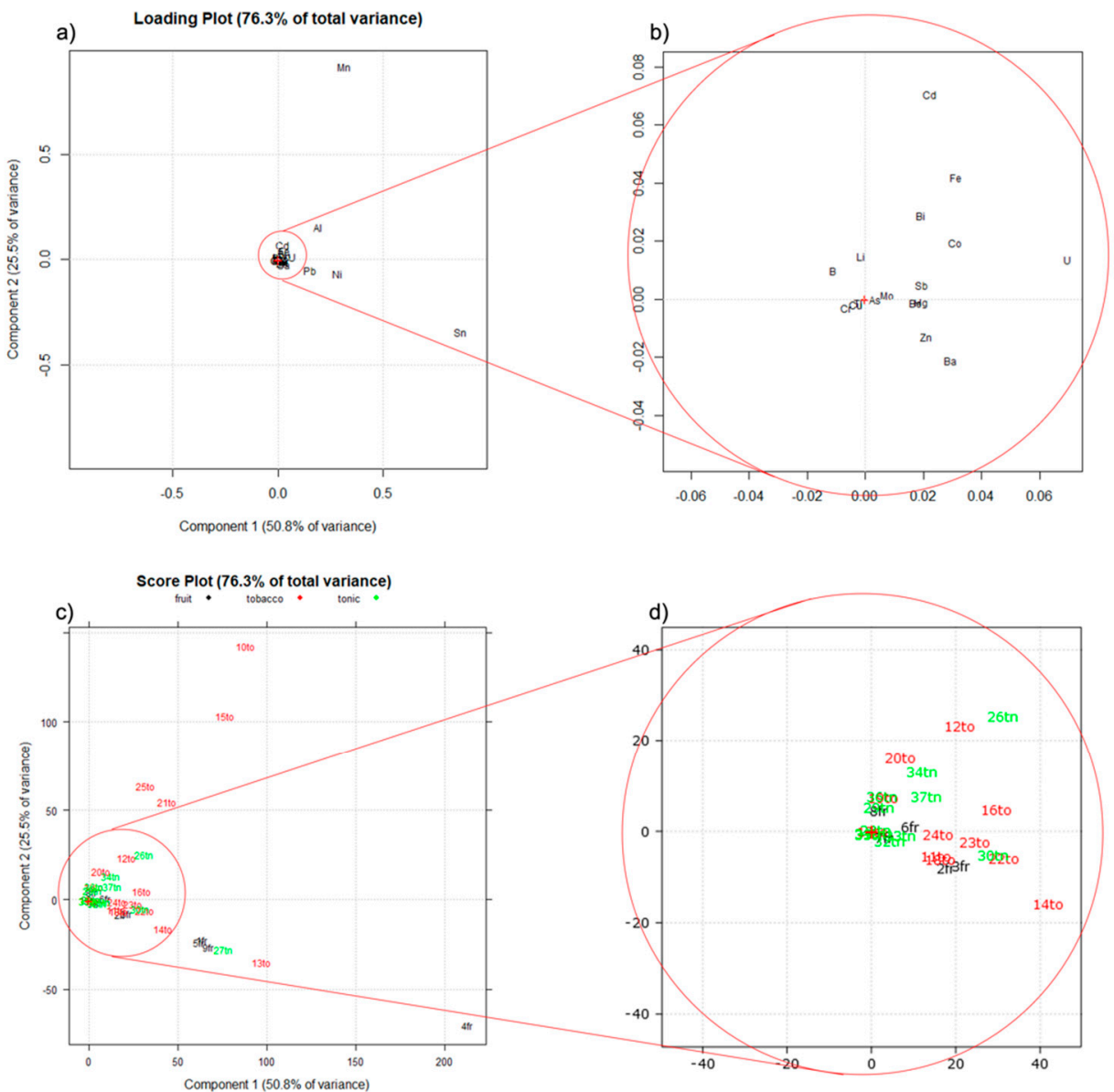

Figure 5. PCA performed on the same dataset processed and normalized, for each analyte, with respect to the relevant concentration measured in the synthetic matrix (SM). (a) Loading plot; (b) zoomed view of the loading plot; (c) score plot; (d) zoomed view of the score plot; to: tobacco flavored samples; fr: fruity-flavored samples; tn: tonic-flavored samples.

The two principal components explain $76 \%$ of the total variance. In the loading plot (Figure 5a,b), 17 out the 22 elements quantified are crowded around the center of the plot, giving no contribution to the explained variance, whereas elements such as $\mathrm{Al}, \mathrm{Pb}, \mathrm{Ni}$, and mainly $\mathrm{Mn}$ and $\mathrm{Sn}$ are responsible for the variability expressed by the first two components. In the score plot, most of the samples are grouped in the origin of the two PC axes, with only a few samples highly differing from the others. To interpret the obtained PCA, it must be kept in mind that data were normalized with respect to the concentrations of the elements in the SM; this means that the samples grouping around the origin of the axes in the score plot (Figure 5c,d) show no variability with respect to the SM, whereas samples distant from the origin are those that mostly differ from the SM. This difference is due 
to a few elements ( $\mathrm{Mn}, \mathrm{Sn}$ and, to a minor extent, $\mathrm{Al}, \mathrm{Pb}$, and $\mathrm{Ni}$ are responsible for the variability seen in the plots). This means that the tobacco samples 10to, 15to, 21to, and 25to, described by high positive score values of $\mathrm{PC} 2$, are the richest in $\mathrm{Al}$ and, in particular, $\mathrm{Mn}$, with respect to the SM. On the other hand, the samples 4fr, 13to, 27tn, 5fr, 9fr, and 1fr, described by high positive score values of PC1 and negative score values of PC2, are richer in $\mathrm{Sn}, \mathrm{Ni}$, and $\mathrm{Pb}$, with respect to the $\mathrm{SM}$.

Looking at the zoomed view of the plots (Figure $5 b, d$ ), it is interesting to observe that positive scores of PC1 are correlated by the increase of the amount of each analyte in the e-liquid, with respect to the amount present in the SM. The almost complete absence of elements and samples described by negative scores of PC1 is, in our opinion, a clear marker of the overall reliability of the data here obtained. Summarizing, Sn, Mn, and-in decreasing amounts - $\mathrm{Ni}, \mathrm{Al}$, and $\mathrm{Pb}$, are elements that mainly originated from the flavors, whereas the remaining elements are derived mainly from the constant compounds of the e-liquids, i.e., PG, VG, and water. In addition, it is interesting to observe that tonic e-liquids are the category closest to the matrix concentration, whereas fruity and tobacco e-liquids are the most scattered samples.

\section{Materials and Methods}

\subsection{Samples and Reagents}

The 37 samples of e-liquids were provided by a local producer. Eight of them were fruity-flavored, twelve were tonic-flavored, and seventeen were tobacco-flavored. Table 6 reports the composition of each class of e-liquids.

Table 6. Composition of the three classes of e-liquids.

\begin{tabular}{ccccc}
\hline e-Liquid Flavor Class & PG (\%) & VG (\%) & $\begin{array}{c}\text { Concentrated } \\
\text { Flavor (\%) }\end{array}$ & Water (\%) \\
\hline Fruity & 50 & 40 & 8 & 2 \\
Tobacco & 50 & 40 & 6 & 4 \\
Tonic & 50 & 40 & 7 & 3 \\
\hline
\end{tabular}

The same producer also provided the pure compounds (i.e., propylene glycol, glycerin, and water) that were added to the concentrated flavor to produce the samples analyzed. Albeit they were all nicotine-free, the producer also provided a sample of pure nicotine to evaluate its contribution to the overall amount of trace elements in the nicotineadded e-liquids.

$\mathrm{HNO}_{3}$ 69\% (NORMATON for ultra-trace analysis, VWR, Milan, Italy) and type I water (MilliQ plus System, Millipore, Vimodrone, Italy) were used in all the phases of the study. Triton ${ }^{\mathrm{TM}}$ X-100 aqueous solution, $10 \%(w / v)$ was from Merck, Milan, Italy. ICP-MS elemental standards of $\mathrm{Al}, \mathrm{As}, \mathrm{B}, \mathrm{Ba}, \mathrm{Be}, \mathrm{Bi}, \mathrm{Cd}, \mathrm{Co}, \mathrm{Cr}, \mathrm{Cu}, \mathrm{Fe}, \mathrm{Hg}$, Li, Mn, Mo, Ni, Pb, Sb, $\mathrm{Sn}, \mathrm{Tl}, \mathrm{U}$, and $\mathrm{Zn}\left(1000 \mathrm{mg} \mathrm{dm}^{-3}\right.$ each) were purchased from LabKings (Hilversum, The Netherlands). The ICP-MS setup solution (a $1 \% v / v$ aqueous solution of $\mathrm{HNO}_{3}$ containing $1 \mu \mathrm{g} \mathrm{dm}^{-3}$ each of $\mathrm{Be}, \mathrm{Ce}, \mathrm{Fe}, \mathrm{In}, \mathrm{Li}, \mathrm{Mg}, \mathrm{Pb}$, and $\left.\mathrm{U}\right)$, the ICP-MS KED setup solution (a $1 \%(v / v)$ aqueous solution of $\mathrm{HNO}_{3}$ containing $10 \mu \mathrm{g} \mathrm{dm}^{-3}$ of Co and $1 \mu \mathrm{g} \mathrm{dm} \mathrm{dm}^{-3}$ of $\mathrm{Ce})$, and the internal standard solution $\left(10 \mu \mathrm{g} \mathrm{dm}{ }^{-3}\right.$ of $\mathrm{Rh}$ in a $1 \% v / v$ aqueous solution of $\mathrm{HNO}_{3}$ ) were all from Perkin Elmer, Milan, Italy. All the samples were filtered before the analysis using a polypropylene filter (pore diameter: $0.22 \mu \mathrm{m}$ ) from VWR, Milan, Italy.

\subsection{Instrumentation}

The samples were mineralized using a microwave SRC system (UltraWave ${ }^{\mathrm{TM}}$, Milestone, Sorisole, Italy). The elemental determination was performed using a NexION 300X ICP-MS spectrometer (Perkin Elmer, Milan, Italy) equipped with a nebulization system composed of a glass concentric nebulizer, a glass cyclonic spray chamber, an autosampler model S10, and a KED collision cell. All the elements were determined simultaneously, and 
the information about the analytes and operational conditions has already been reported in Table 1.

\subsection{Statistical Analysis}

Principal components analysis (PCA) was performed by means of the R-based software Chemometric Agile Tool (CAT) developed by the Italian group of chemometrics [68].

\section{Conclusions}

The perceived need in the literature for sensitive, reliable, and validated ICP-MS methods to quantify a wide range of both toxic elements and oligoelements in e-liquids is the main reason for accomplishing this study. Hence, an original method capable of determining the concentration of 23 elements in such a matrix has been developed and validated in terms of LoD, LoQ, precision, and trueness. The need to circumvent the very strong matrix effect has required the introduction of significant changes with respect to the methods described in the literature. Namely, the sample pre-treatment step has been accomplished by microwave-assisted mineralization. Moreover, the ICP-MS instrumental parameters have been optimized to enhance the sensitivity and reduce the spectral interference by the polyatomic ions. Finally, the quantification, performed by means of an internal calibration with three additions of standards, has allowed for the obtainment of accurate data. The method has been applied to 37 different e-liquids of three different classes of flavors (i.e., fruity, tobacco, and tonic). The average concentration of all analytes is aligned with the lowest amounts measured in the literature, confirming hence that, also in this case, the potential health risk related to the amount of toxic elements in e-liquids is orders of magnitude less than that measured for traditional cigarettes. Almost all toxic elements have been found below an amount lower than a few $\mu \mathrm{g} \mathrm{kg}^{-1}$ and, very often, they were below the relevant LoQ. The data obtained also give an account for the slight differences among the classes of flavors. Tobacco and tonic flavors exhibit the highest and the lowest amounts of elements, respectively. The results of the PCA showed that the multivariate approach allowed easy differentiation of the elements derived from constituents and those from added flavors. For this reason, this approach may be generalized in order to minimize the amount of each element in the final e-liquids. In conclusion, e-liquids seem to be scarcely involved as potential sources of toxic elements inhaled by vapers. Hence, further investigations are needed to ascertain the influence of the conditions of use for e-cigarettes on the dragging in the vapor phase for the elements of potential toxicity in humans.

Supplementary Materials: The following table is available online. Table S1. Elemental concentration of toxic elements and oligoelements in 37 different e-liquids.

Author Contributions: Conceptualization, A.M. and G.S.; methodology, A.M., M.D. and G.S.; validation, A.M., I.L. and G.S.; formal analysis, A.M. and M.C.; investigation, A.M., I.L., S.D. P.M. and M.D.; resources, G.S.; data curation, A.M., M.C. and G.S.; writing—original draft preparation, A.M., M.C. and G.S.; writing—review and editing, A.M., I.L., M.C., M.I.P., N.S. and G.S.; visualization, A.M., M.C. and G.S.; supervision, G.S.; project administration, G.S.; funding acquisition, G.S. All authors have read and agreed to the published version of the manuscript.

Funding: This research was funded by Università degli Studi di Sassari (“Fondo di Ateneo per la ricerca $2020^{\prime \prime}$ ).

Institutional Review Board Statement: Not applicable.

Informed Consent Statement: Not applicable.

Acknowledgments: The authors gratefully thank the New Flavours company, Sassari, Sardinia, Italy, for the generous supply of e-liquids and their common co-formulants (i.e., PG, VG, water, and nicotine). Moreover, the GAUSS UNISS, Grandi Attrezzature Università di Sassari is gratefully acknowledged for the access granted to their ICP-MS instrument. 
Conflicts of Interest: The authors declare no conflict of interest.

Sample Availability: Samples of the compounds are not available from the authors but may be requested from the New Flavours company.

\section{References}

1. Williams, M.; Talbot, P. Variability Among Electronic Cigarettes in the Pressure Drop, Airflow Rate, and Aerosol Production. Nicotine Tob. Res. 2011, 13, 1276-1283. [CrossRef]

2. Breland, A.; Soule, E.; Lopez, A.; Ramôa, C.; El-Hellani, A.; Eissenberg, T. Electronic cigarettes: What are they and what do they do? Ann. N. Y. Acad. Sci. 2017, 1394, 5-30. [CrossRef]

3. European Commission. Food Additives. E1520. Propane-1,2-Diol (Propylene Glycol). Available online: https://webgate.ec. europa.eu/foods_system/main/index.cfm?event=substance.view\&identifier=351 (accessed on 12 October 2021).

4. European Commission. Food Additives. E422. Glycerol. Available online: https://webgate.ec.europa.eu/foods_system/main/ index.cfm?event=substance.view\&identifier=166 (accessed on 12 October 2021).

5. European Directive 2014/40/EU of the European Parliament and of the Council of 3 April 2014 on the approximation of the laws, regulations and administrative provisions of the Member States concerning the manufacture, presentation and sale of tobacco and related products and repealing Directive 2001/37/EC Text with EEA relevance. Off. J. Eur. Union. L 2014, 127/1. Available online: https:/ / eur-lex.europa.eu/legal-content/EN/TXT/HTML/?uri=CELEX:32014L0040\&from=EN (accessed on 12 October 2021).

6. Talhout, R.; Schulz, T.; Florek, E.; Van Benthem, J.; Wester, P.; Opperhuizen, A. Hazardous Compounds in Tobacco Smoke. Int. J. Environ. Res. Public Health 2011, 8, 613-628. [CrossRef]

7. Goniewicz, M.L.; Knysak, J.; Gawron, M.; Kosmider, L.; Sobczak, A.; Kurek, J.; Prokopowicz, A.; Jabłońska-Czapla, M.; RosikDulewska, C.; Havel, C.; et al. Levels of selected carcinogens and toxicants in vapour from electronic cigarettes. Tob. Control. 2013, 23, 133-139. [CrossRef]

8. Hecht, S.S.; Carmella, S.G.; Kotandeniya, D.; Pillsbury, M.E.; Chen, M.; Ransom, B.W.S.; Vogel, R.; Thompson, E.; Murphy, S.E.; Hatsukami, D.K. Evaluation of Toxicant and Carcinogen Metabolites in the Urine of E-Cigarette Users Versus Cigarette Smokers. Nicotine Tob. Res. 2015, 17, 704-709. [CrossRef] [PubMed]

9. Grana, R.; Benowitz, N.; Glantz, S.A. E-Cigarettes. Circulation 2014, 129, 1972-1986. [CrossRef] [PubMed]

10. Pisinger, C.; Døssing, M. A systematic review of health effects of electronic cigarettes. Prev. Med. 2014, 69, 248-260. [CrossRef]

11. Wang, G.; Liu, W.; Song, W. Toxicity assessment of electronic cigarettes. Inhal. Toxicol. 2019, 31, 259-273. [CrossRef]

12. Sapru, S.; Vardhan, M.; Li, Q.; Guo, Y.; Li, X.; Saxena, D. E-cigarettes use in the United States: Reasons for use, perceptions, and effects on health. BMC Public Health 2020, 20, 1518. [CrossRef]

13. Cao, Y.; Wu, D.; Ma, Y.; Ma, X.; Wang, S.; Li, F.; Li, M.; Zhang, T. Toxicity of electronic cigarettes: A general review of the origins, health hazards, and toxicity mechanisms. Sci. Total. Environ. 2021, 772, 145475. [CrossRef]

14. Chun, L.F.; Moazed, F.; Calfee, C.S.; Matthay, M.A.; Gotts, J.E. Pulmonary toxicity of e-cigarettes. Am. J. Physiol. Lung Cell. Mol. Physiol. 2017, 313, L193-L206. [CrossRef] [PubMed]

15. Leigh, N.J.; Tran, P.L.; O'Connor, R.J.; Goniewicz, M.L. Cytotoxic effects of heated tobacco products (HTP) on human bronchial epithelial cells. Tob. Control. 2018, 27, s26-s29. [CrossRef]

16. Putzhammer, R.; Doppler, C.; Jakschitz, T.; Heinz, K.; Förste, J.; Danzl, K.; Messner, B.; Bernhard, D. Vapours of US and EU Market Leader Electronic Cigarette Brands and Liquids Are Cytotoxic for Human Vascular Endothelial Cells. PLoS ONE 2016, 11, e0157337. [CrossRef]

17. Carnevale, R.; Sciarretta, S.; Violi, F.; Nocella, C.; Loffredo, L.; Perri, L.; Peruzzi, M.; Marullo, A.G.M.; De Falco, E.; Chimenti, I.; et al. Acute Impact of Tobacco vs. Electronic Cigarette Smoking on Oxidative Stress and Vascular Function. Chest 2016, 150, 606-612. [CrossRef]

18. Kuntic, M.; Oelze, M.; Steven, S.; Kröller-Schön, S.; Stamm, P.; Kalinovic, S.; Frenis, K.; Vujacic-Mirski, K.; Jimenez, M.T.B.; Kvandova, M.; et al. Short-term e-cigarette vapour exposure causes vascular oxidative stress and dysfunction: Evidence for a close connection to brain damage and a key role of the phagocytic NADPH oxidase (NOX-2). Eur. Heart J. 2020, 41, $2472-2483$. [CrossRef]

19. Whittington, J.R.; Simmons, P.M.; Phillips, A.M.; Gammill, S.K.; Cen, R.; Magann, E.F.; Cardenas, V.M. The Use of Electronic Cigarettes in Pregnancy: A Review of the Literature. Obstet. Gynecol. Surv. 2018, 73, 544-549. [CrossRef]

20. Schweitzer, K.S.; Chen, S.X.; Law, S.; Van Demark, M.; Poirier, C.; Justice, M.J.; Hubbard, W.C.; Kim, E.S.; Lai, X.; Wang, M.; et al. Endothelial disruptive proinflammatory effects of nicotine and e-cigarette vapor exposures. Am. J. Physiol. Lung Cell. Mol. Physiol. 2015, 309, L175-L187. [CrossRef] [PubMed]

21. Vansickel, A.R.; Cobb, C.O.; Weaver, M.F.; Eissenberg, T.E. A Clinical Laboratory Model for Evaluating the Acute Effects of Electronic "Cigarettes": Nicotine Delivery Profile and Cardiovascular and Subjective Effects. Cancer Epidemiol. Biomark. Prev. 2010, 19, 1945-1953. [CrossRef]

22. Bodas, M.; Van Westphal, C.; Carpenter-Thompson, R.; Mohanty, D.K.; Vij, N. Nicotine exposure induces bronchial epithelial cell apoptosis and senescence via ROS mediated autophagy-impairment. Free Radic. Biol. Med. 2016, 97, 441-453. [CrossRef] [PubMed] 
23. Bekki, K.; Uchiyama, S.; Ohta, K.; Inaba, Y.; Nakagome, H.; Kunugita, N. Carbonyl Compounds Generated from Electronic Cigarettes. Int. J. Environ. Res. Public Health 2014, 11, 11192-11200. [CrossRef] [PubMed]

24. Khlystov, A.; Samburova, V. Flavoring Compounds Dominate Toxic Aldehyde Production during E-Cigarette Vaping. Environ. Sci. Technol. 2016, 50, 13080-13085. [CrossRef]

25. Beauval, N.; Antherieu, S.; Soyez, M.; Gengler, N.; Grova, N.; Howsam, M.; Hardy, E.M.; Fischer, M.; Appenzeller, B.M.R.; Goossens, J.-F.; et al. Chemical Evaluation of Electronic Cigarettes: Multicomponent Analysis of Liquid Refills and their Corresponding Aerosols. J. Anal. Toxicol. 2017, 41, 670-678. [CrossRef]

26. Kim, H.-J.; Shin, H.-S. Determination of tobacco-specific nitrosamines in replacement liquids of electronic cigarettes by liquid chromatography-tandem mass spectrometry. J. Chromatogr. A 2013, 1291, 48-55. [CrossRef]

27. Famele, M.; Ferranti, C.; Abenavoli, C.; Palleschi, L.; Mancinelli, R.; Draisci, R. The Chemical Components of Electronic Cigarette Cartridges and Refill Fluids: Review of Analytical Methods. Nicotine Tob. Res. 2015, 17, 271-279. [CrossRef]

28. Bansal, V.; Kim, K.-H. Review on quantitation methods for hazardous pollutants released by e-cigarette (EC) smoking. TrAC Trends Anal. Chem. 2016, 78, 120-133. [CrossRef]

29. Ogunwale, M.A.; Li, M.; Raju, M.V.R.; Chen, Y.; Nantz, M.H.; Conklin, D.J.; Fu, X.-A. Aldehyde Detection in Electronic Cigarette Aerosols. ACS Omega 2017, 2, 1207-1214. [CrossRef] [PubMed]

30. Behar, R.Z.; Davis, B.; Wang, Y.; Bahl, V.; Lin, S.; Talbot, P. Identification of toxicants in cinnamon-flavored electronic cigarette refill fluids. Toxicol. Vitr. 2014, 28, 198-208. [CrossRef] [PubMed]

31. Pappas, R.S.; Polzin, G.M.; Zhang, L.; Watson, C.H.; Paschal, D.C.; Ashley, D.L. Cadmium, lead, and thallium in mainstream tobacco smoke particulate. Food Chem. Toxicol. 2006, 44, 714-723. [CrossRef]

32. Fresquez, M.R.; Pappas, R.S.; Watson, C.H. Establishment of Toxic Metal Reference Range in Tobacco from US Cigarettes. J. Anal. Toxicol. 2013, 37, 298-304. [CrossRef]

33. Hess, C.A.; Olmedo, P.; Navas-Acien, A.; Goessler, W.; Cohen, J.E.; Rule, A.M. E-cigarettes as a source of toxic and potentially carcinogenic metals. Environ. Res. 2017, 152, 221-225. [CrossRef]

34. Badea, M.; Luzardo, O.P.; González-Antuña, A.; Zumbado, M.; Rogozea, L.; Floroian, L.; Alexandrescu, D.; Moga, M.; Gaman, L.; Radoi, M.; et al. Body burden of toxic metals and rare earth elements in non-smokers, cigarette smokers and electronic cigarette users. Environ. Res. 2018, 166, 269-275. [CrossRef] [PubMed]

35. Zhao, D.; Aravindakshan, A.; Hilpert, M.; Olmedo, P.; Rule, A.M.; Navas-Acien, A.; Aherrera, A. Metal/Metalloid Levels in Electronic Cigarette Liquids, Aerosols, and Human Biosamples: A Systematic Review. Environ. Health Perspect. 2020, $128,036001$. [CrossRef] [PubMed]

36. Olmedo, P.; Goessler, W.; Tanda, S.; Grau-Perez, M.; Jarmul, S.; Aherrera, A.; Chen, R.; Hilpert, M.; Cohen, J.E.; NavasAcien, A.; et al. Metal Concentrations in e-Cigarette Liquid and Aerosol Samples: The Contribution of Metallic Coils. Environ. Health Perspect. 2018, 126, 027010. [CrossRef]

37. Palazzolo, D.L.; Crow, A.P.; Nelson, J.M.; Johnson, R.A. Trace Metals Derived from Electronic Cigarette (ECIG) Generated Aerosol: Potential Problem of ECIG Devices That Contain Nickel. Front. Physiol. 2017, 7, 663. [CrossRef] [PubMed]

38. Zhao, J.; Nelson, J.; Dada, O.; Pyrgiotakis, G.; Kavouras, I.G.; Demokritou, P. Assessing electronic cigarette emissions: Linking physico-chemical properties to product brand, e-liquid flavoring additives, operational voltage and user puffing patterns. Inhal. Toxicol. 2018, 30, 78-88. [CrossRef] [PubMed]

39. Mikheev, V.B.; Brinkman, M.C.; Granville, C.A.; Gordon, S.M.; Clark, P.I. Real-Time Measurement of Electronic Cigarette Aerosol Size Distribution and Metals Content Analysis. Nicotine Tob. Res. 2016, 18, 1895-1902. [CrossRef] [PubMed]

40. Halstead, M.; Gray, N.; Gonzalez-Jimenez, N.; Fresquez, M.; Valentin-Blasini, L.; Watson, C.; Pappas, R.S. Analysis of Toxic Metals in Electronic Cigarette Aerosols Using a Novel Trap Design. J. Anal. Toxicol. 2020, 44, 149-155. [CrossRef] [PubMed]

41. Beauval, N.; Howsam, M.; Antherieu, S.; Allorge, D.; Soyez, M.; Garçon, G.; Goossens, J.F.; Lo-Guidice, J.M.; Garat, A. Trace elements in e-liquids-Development and validation of an ICP-MS method for the analysis of electronic cigarette refills. Regul. Toxicol. Pharmacol. 2016, 79, 144-148. [CrossRef]

42. Flora, J.W.; Meruva, N.; Huang, C.B.; Wilkinson, C.T.; Ballentine, R.; Smith, D.C.; Werley, M.S.; McKinney, W.J. Characterization of potential impurities and degradation products in electronic cigarette formulations and aerosols. Regul. Toxicol. Pharmacol. 2016, 74, 1-11. [CrossRef]

43. Song, J.-J.; Go, Y.Y.; Mun, J.Y.; Lee, S.; Im, G.J.; Kim, Y.Y.; Lee, J.H.; Chang, J. Effect of electronic cigarettes on human middle ear. Int. J. Pediatr. Otorhinolaryngol. 2018, 109, 67-71. [CrossRef] [PubMed]

44. Tayyarah, R.; Long, G.A. Comparison of select analytes in aerosol from e-cigarettes with smoke from conventional cigarettes and with ambient air. Regul. Toxicol. Pharmacol. 2014, 70, 704-710. [CrossRef] [PubMed]

45. Margham, J.; McAdam, K.; Forster, M.; Liu, C.; Wright, C.; Mariner, D.; Proctor, C. Chemical Composition of Aerosol from an E-Cigarette: A Quantitative Comparison with Cigarette Smoke. Chem. Res. Toxicol. 2016, 29, 1662-1678. [CrossRef]

46. Zhao, D.; Navas-Acien, A.; Ilievski, V.; Slavkovich, V.; Olmedo, P.; Adria-Mora, B.; Domingo-Relloso, A.; Aherrera, A.; Kleiman, N.J.; Rule, A.M.; et al. Metal concentrations in electronic cigarette aerosol: Effect of open-system and closed-system devices and power settings. Environ. Res. 2019, 174, 125-134. [CrossRef]

47. Williams, M.; Villarreal, A.; Bozhilov, K.; Lin, S.; Talbot, P. Metal and Silicate Particles Including Nanoparticles Are Present in Electronic Cigarette Cartomizer Fluid and Aerosol. PLoS ONE 2013, 8, e57987. [CrossRef] 
48. Williams, M.; To, A.; Bozhilov, K.; Talbot, P. Strategies to Reduce Tin and Other Metals in Electronic Cigarette Aerosol. PLoS ONE 2015, 10, e0138933. [CrossRef]

49. Williams, M.; Bozhilov, K.; Ghai, S.; Talbot, P. Elements including metals in the atomizer and aerosol of disposable electronic cigarettes and electronic hookahs. PLoS ONE 2017, 12, e0175430. [CrossRef] [PubMed]

50. Williams, M.; Bozhilov, K.N.; Talbot, P. Analysis of the elements and metals in multiple generations of electronic cigarette atomizers. Environ. Res. 2019, 175, 156-166. [CrossRef] [PubMed]

51. Kamilari, E.; Farsalinos, K.; Poulas, K.; Kontoyannis, C.G.; Orkoula, M.G. Detection and quantitative determination of heavy metals in electronic cigarette refill liquids using Total Reflection X-ray Fluorescence Spectrometry. Food Chem. Toxicol. 2018, 116, 233-237. [CrossRef]

52. AFNOR. XP D90-300-2-Electronic Cigarettes and E-Liquids-Part 2: Requirements and Test Methods for E-Liquids; European Association for the Co-ordination of Consumers Representation in Standardisation; AISBL Press: Brussels, Belgium, 2015.

53. BSI. PAS 54115:2015-Vaping Products, including Electronic Cigarettes, e-Liquids, e-Shisha and Directly-Related Products. In Manufacture, Importation, Testing and Labelling Guide; British Standards Institution (BSI) Press: London, UK, 2015.

54. European Association for the Coordination of Consumer Representation in Standardization (ANEC). E-Cigarettes and E-Liquids —Limits for Chemicals; Basis for discussion. Position Paper ANEC-PT-2019-CEG-005; ANEC: Brussels, Belgium, 2019. Available online: https:/ / www.anec.eu/images/Publications/position-papers/Chemicals/ANEC-PT-2019-CEG-005.pdf (accessed on 12 October 2021).

55. Langasco, I.; Caredda, M.; Sanna, G.; Panzanelli, A.; Pilo, M.I.; Spano, N.; Petretto, G.; Urgeghe, P.P. Chemical Characterization of Craft Filuferru Spirit from Sardinia, Italy. Beverages 2018, 4, 62. [CrossRef]

56. Spanu, A.; Valente, M.; Langasco, I.; Leardi, R.; Orlandoni, A.M.; Ciulu, M.; Deroma, M.A.; Spano, N.; Barracu, F.; Pilo, M.I.; et al. Effect of the irrigation method and genotype on the bioaccumulation of toxic and trace elements in rice. Sci. Total. Environ. 2020, 748, 142484. [CrossRef]

57. Langasco, I.; Barracu, F.; Deroma, M.A.; López-Sánchez, J.F.; Mara, A.; Meloni, P.; Pilo, M.I.; Estrugo, À.S.; Sanna, G.; Spano, N.; et al. Assessment and validation of ICP-MS and IC-ICP-MS methods for the determination of total, extracted and speciated As. Application to samples from a soil-rice system at varying the irrigation method. J. Env. Manag. 2021. submitted.

58. May, T.W.; Wiedmeyer, R.H. A Table of Polyatomic Interferences in ICP-MS. At. Spectrosc. 1998, 19, $150-155$.

59. Spanu, A.; Langasco, I.; Valente, M.; Deroma, M.A.; Spano, N.; Barracu, F.; Pilo, M.I.; Sanna, G. Tuning of the Amount of Se in Rice (Oryza sativa) Grain by Varying the Nature of the Irrigation Method: Development of an ICP-MS Analytical Protocol, Validation and Application to 26 Different Rice Genotypes. Molecules 2020, 25, 1861. [CrossRef] [PubMed]

60. Goncalves, D.A.; Jones, B.T.; Donati, G.L. The reversed-axis method to estimate precision in standard additions analysis. Microchem. J. 2016, 124, 155-158. [CrossRef]

61. Andersen, J.E.T. The standard addition method revisited. TrAC Trends Anal. Chem. 2017, 89, 21-33. [CrossRef]

62. Harris, D.C. Quantitative Chemical Analysis, 8th ed.; W.H. Freeman: New York, NY, USA, 2010.

63. Currie, L.A. Nomenclature in evaluation of analytical methods including detection and quantification capabilities. Anal. Chim. Acta 1999, 391, 105-126. [CrossRef]

64. Chemnitzer, R. Strategies for Achieving the Lowest Possible Detection Limits in ICP-MS. Spectrosc. (St. Monica) 2019, 34, 12-16. Available online: https:/ / www.spectroscopyonline.com/view/strategies-achieving-lowest-possible-detection-limits-icp-ms (accessed on 12 October 2021).

65. Council of the European Union. Council Directive 98/83/EC of 3 November 1998 on the Quality of Water Intended for Human Consumption. Off. J. Eur. Union. L 1998, 330, 32-54. Available online: https://eur-lex.europa.eu/legal-content/EN/TXT/PDF/ ?uri=CELEX:31998L0083\&from=IT (accessed on 12 October 2021).

66. Water quality_Application of inductively coupled plasma mass spectrometry (ICP-MS)—Part 1: General Guidelines. In International Organization for Standardization: Method ISO 17294-1; ISO: Geneva, Switzerland, 2004.

67. Water quality-Application of inductively coupled plasma mass spectrometry (ICP-MS)—Part 2, determination of selected elements including uranium isotopes. In International Organization for Standardization: Method ISO 17294-2; ISO: Geneva, Switzerland, 2016.

68. CAT (Chemometric Agile Tool). Available online: http://gruppochemiometria.it/index.php/software (accessed on 12 October 2021). 